\title{
Impact of the isoprene photochemical cascade on tropical ozone
}

\author{
F. Paulot ${ }^{1, *}$, D. K. Henze ${ }^{2}$, and P. O. Wennberg ${ }^{1,3}$ \\ ${ }^{1}$ Division of Engineering and Applied Sciences, California Institute of Technology, Pasadena, California, USA \\ ${ }^{2}$ Department of Mechanical Engineering, University of Colorado, Boulder, Colorado, USA \\ ${ }^{3}$ Division of Geological and Planetary Sciences, California Institute of Technology, Pasadena, California, USA \\ *now at: Harvard University Center for the Environment, Harvard University, Cambridge, Massachusetts, USA
}

Correspondence to: F. Paulot (paulot@ seas.harvard.edu)

Received: 20 July 2011 - Published in Atmos. Chem. Phys. Discuss.: 13 September 2011

Revised: 22 December 2011 - Accepted: 13 January 2012 - Published: 2 February 2012

\begin{abstract}
Tropical tropospheric ozone affects Earth's radiative forcing and the oxidative capacity of the atmosphere. Considerable work has been devoted to the study of the processes controlling its budget. Yet, large discrepancies between simulated and observed tropical tropospheric ozone remain. Here, we characterize some of the mechanisms by which the photochemistry of isoprene impacts the budget of tropical ozone. At the regional scale, we use forward sensitivity simulation to explore the sensitivity to the representation of isoprene nitrates. We find that isoprene nitrates can account for up to $70 \%$ of the local $\mathrm{NO}_{\mathrm{x}}=\mathrm{NO}+\mathrm{NO}_{2}$ sink. The resulting modulation of ozone can be well characterized by their net modulation of $\mathrm{NO}_{\mathrm{x}}$. We use adjoint sensitivity simulations to demonstrate that the oxidation of isoprene can affect ozone outside of continental regions through the transport of $\mathrm{NO}_{\mathrm{x}}$ over near-shore regions (e.g., South Atlantic) and the oxidation of isoprene outside of the boundary layer far from its emissions regions. The latter mechanism is promoted by the simulated low boundary-layer oxidative conditions. In our simulation, $\sim 20 \%$ of the isoprene is oxidized above the boundary layer in the tropics. Changes in the interplay between regional and global effect are discussed in light of the forecasted increase in anthropogenic emissions in tropical regions.
\end{abstract}

\section{Introduction}

The impact of tropical ozone on Earth's radiative forcing (Forster et al., 2007) and oxidative capacity have motivated considerable work to unravel the complex interplay between dynamics, surface emissions and chemistry that controls its distribution. Spatial patterns such as the South Atlantic ozone maximum (Thompson et al., 2000; Wang et al., 2006) have been explored in great depth and the sensitivity of ozone to NO emissions from lightning (Sauvage et al., 2007b), biomass burning (Jacob et al., 1996; Chandra et al., 2002; Ziemke and Chandra, 1999; Jourdain et al., 2007; Edwards et al., 2006) and soil (Jaeglé et al., 2004) or to dynamics (Wang et al., 2006; Nassar et al., 2009) has been characterized. However, significant discrepancies between model and observations remain (Zhang et al., 2010). Since ozone is photochemically produces, we focus here on the uncertainties in the chemical transfer function that relates emissions and ozone, a topic that has been seldom addressed (Bowman et al., 2009).

The tropics are characterized by very large biogenic emissions, whose photooxidation impacts the budgets of $\mathrm{O}_{\mathrm{x}}=\mathrm{O}_{3}+\mathrm{NO}_{2}$ and $\mathrm{HO}_{\mathrm{x}}=\mathrm{OH}+\mathrm{HO}_{2}$ (Lelieveld et al., 2008). The influence of the photooxidation of isoprene, a fivecarbon dialkene that accounts for $30 \%$ to $50 \%$ of biogenic volatile organic compound (BVOC) emissions (Guenther et al., 1995; Guenther et al., 2006) on photochemistry has recently motivated considerable laboratory (Paulot et al., 2009a,b; Lockwood et al., 2010; Crounse et al., 2011), field (Thornton et al., 2002; Ren et al., 2008; Lelieveld et al., 2008) and theoretical work (Peeters et al., 2009; Dibble, 2004a,b). Simulations suggest that the effect of isoprene chemistry on the $\mathrm{O}_{\mathrm{x}}$ budget extends to much larger scale than isoprene's short atmospheric lifetime would suggest (Roelofs and Lelieveld, 2000; von Kuhlmann et al., 2004; Pfister et al., 2008). In this study, we first use forward sensitivity simulations to show that the impact of different representations of isoprene nitrate chemistry on the regional 
Table 1. Summary of the changes to the standard GEOS-Chem mechanism (Horowitz et al. (1998), see also http://acmg.seas.harvard.edu/ geos/wiki_docs/chemistry/chemistry_updates_v6.pdf)

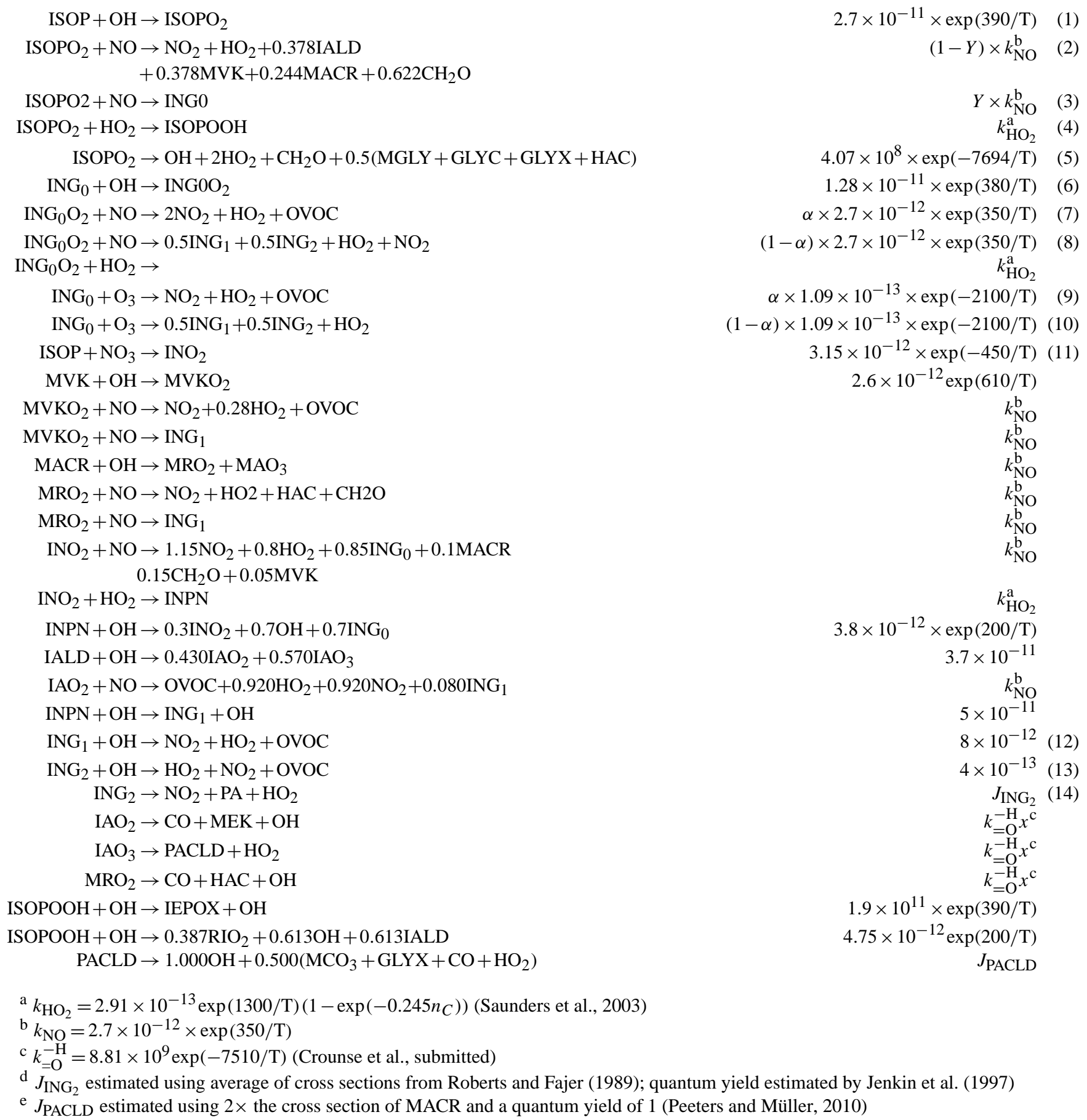

budget of ozone can be well understood by characterizing their overall impact on $\mathrm{NO}_{\mathrm{x}}$. We then use adjoint sensitivity simulations to trace the processes that contribute to the long-range influence of the isoprene photochemical cascade on tropical ozone.
The photooxidation of isoprene is primarily initiated by its reaction with $\mathrm{OH}$ (Table 1, Reaction (R1)). This reaction produces isoprene peroxy radicals $\left(\mathrm{ISOPO}_{2}\right)$, whose fate is critical to the $\mathrm{O}_{\mathrm{x}}$ budget. When $\mathrm{ISOPO}_{2}$ reacts with NO, isoprene photooxidation promotes $\mathrm{O}_{\mathrm{x}}$ formation (Reation (R2)). 
This reaction is especially important in regions where urban centers are embedded in forested areas (e.g., Atlanta, Chameides et al. (1988)). The auto-catalytic production of $\mathrm{O}_{\mathrm{x}}$ is terminated by radical losses, e.g., the formation of nitric acid $\left(\mathrm{OH}+\mathrm{NO}_{2} \rightarrow \mathrm{HNO}_{3}\right)$ and hydrogen peroxide $\left(\mathrm{HO}_{2}+\mathrm{HO}_{2} \rightarrow \mathrm{H}_{2} \mathrm{O}_{2}\right)$. Since the ozone production efficiency (OPE) - the number of molecules of $\mathrm{O}_{3}$ produced per molecule of $\mathrm{NO}_{\mathrm{x}}$ consumed (Liu et al., 1987) - generally increases as the ratio of $\mathrm{NO}_{\mathrm{x}}$ to VOC decreases (Seinfeld and Pandis, 1998), tropical regions with high isoprene emissions and low anthropogenic $\mathrm{NO}_{\mathrm{x}}$ emissions can be expected to be extremely sensitive to increasing $\mathrm{NO}$ emissions (Thornton et al., 2002). For instance, ozone production in the outflow of Manaus (Brazil) is similar to that of major North American cities (Kuhn et al., 2010).

When $\mathrm{ISOPO}_{2}$ reacts with $\mathrm{HO}_{2}, \mathrm{HO}_{\mathrm{x}}$ is destroyed (Reaction (R4)). This slows the local photochemistry, contributing to the very low ozone levels over remote tropical forests.

Because isoprene emissions are so large, its photooxidation can modulate the local photochemical conditions. Under very low $\mathrm{NO}_{\mathrm{x}}$ conditions, the removal of $\mathrm{HO}_{\mathrm{x}}$ via Reaction (R4) is predicted to result in very low concentrations of $\mathrm{HO}_{\mathrm{x}}$ in the isoprene-rich boundary layer (Houweling et al., 1998). Under these conditions, the lifetime of $\mathrm{ISOPO}_{2}$ can become long $(\sim 60 \mathrm{~s})$ and unimolecular processes (Reaction (R5)) become competitive with Reactions (R4) and (R2) (Peeters et al., 2009; Crounse et al., 2011). This attenuates the removal of $\mathrm{HO}_{\mathrm{x}}$ by isoprene photochemistry, more consistent with field observations of $\mathrm{HO}_{\mathrm{x}}$ (Peeters and Müller, 2010; Stavrakou et al., 2010; Archibald et al., 2010). Here we do not explicitly represent the intermediate carbonyl (HPALD) that is produced by the isomerization and assumes it photolyzes readily (Peeters and Müller, 2010).

Understanding low oxidative photochemical conditions is important for determining the extent of the isoprene photochemical cascade as such conditions promote the transport of isoprene and its photochemical products. In particular, the transport of biogenics to the upper troposphere through convection has been suggested to influence the budget of ozone on the global scale as ozone and $\mathrm{NO}_{\mathrm{x}}$ are much longer lived in this region of the atmosphere than at the surface (Doherty et al., 2005; Collins et al., 1999; Moxim and Levy, 2000).

The modulation of $\mathrm{NO}_{\mathrm{x}}$ through isoprene nitrates $\left(\mathrm{ISOPONO}{ }_{2}\right)$, minor products of the reaction of $\mathrm{ISOPO}_{2}$ with $\mathrm{NO}$, is another mechanism that allows the impact of isoprene photochemistry to propagate to larger scales (e.g., Wu et al., 2007; Gauss et al., 2006; Ito et al., 2007; Horowitz et al., 2007; Fiore et al., 2005; Stevenson et al., 2006). The formation of $\mathrm{ISOPONO}_{2}$ (R3) modulates $\mathrm{O}_{\mathrm{x}}$ by diminishing its local formation through $\mathrm{NO}_{\mathrm{x}}$ sequestration. Furthermore, with high isoprene emissions, the fraction of $\mathrm{NO}_{\mathrm{x}}$ segregated in $\mathrm{ISOPONO}_{2}$ can become large enough that their formation contributes to the loss of $\mathrm{NO}_{\mathrm{x}}$. Unlike nitric acid, usually a terminal sink of $\mathrm{NO}_{\mathrm{x}}$ in the boundary layer, organic nitrates may not be a terminal sink of $\mathrm{NO}_{\mathrm{x}}$ but rather a reservoir (like peroxyacetylnitrate (PAN)). Depending on their lifetime and fate, the transport of these organic nitrates contribute to the export of $\mathrm{NO}_{\mathrm{x}}$ away from its emission regions. The efficiency of this export depends on the fraction of $\mathrm{NO}_{\mathrm{x}}$ that is returned to the atmosphere through the photooxidation of ISOPONO${ }_{2}$ and its nitrate-containing oxidation products $\mathrm{R}^{\star} \mathrm{ONO}_{2}$.

$$
\begin{aligned}
& \mathrm{ISOPONO}_{2} \stackrel{\mathrm{OH}, \mathrm{O}_{3}, h v}{\longrightarrow} \mathrm{NO}_{2} \\
& \stackrel{\mathrm{OH}, \mathrm{O}_{3}, h v}{\longrightarrow} \mathrm{R}^{\star} \mathrm{ONO}_{2} \\
& \stackrel{\text { wet/dry deposition }}{\longrightarrow}
\end{aligned}
$$

There has been considerable laboratory research to determine the yield of $\mathrm{ISOPONO}_{2}(\mathrm{Y}=(\mathrm{R} 3) /((\mathrm{R} 3)+(\mathrm{R} 2)) \sim$ $10 \% \pm 5 \%$, (Chen et al., 1998; Sprengnether et al., 2002; Paulot et al., 2009a; Lockwood et al., 2010). Laboratory (Paulot et al., 2009a; Lockwood et al., 2010) and field observations (Grossenbacher et al., 2001, 2004; Giacopelli et al., 2005; Perring et al., 2009b) suggest isoprene nitrates have a short atmospheric lifetime. However, there is much uncertainty regarding the relative importance of deposition and photochemical sinks (by OH and ozone). Ito et al. (2007) and Perring et al. (2009a) estimated that the fate of isoprene nitrates is dominated by photochemical losses while Horowitz et al. (2007) and Giacopelli et al. (2005) concluded that deposition is their primary sink.

If the isoprene nitrates are primarily lost through photooxidation, assessing their impact on the budget of reactive nitrogen and ozone must include proper representation of their photochemical products (Grossenbacher et al., 2001), about which very little is known. Paulot et al. (2009a) reported the formation of propanone nitrate and ethanal nitrate from ISOPONO$_{2}$ oxidation by $\mathrm{OH}$ and inferred that the ratio of Reactions (R15) to (R16) is $\sim 1$, i.e., that $\sim 50 \%$ of the $\mathrm{NO}_{\mathrm{x}}$ segregated in $\mathrm{ISOPONO}_{2}$ is promptly recycled. In the following we will refer to this fraction as $\alpha$. Similarly, Giacopelli et al. (2005) proposed a suite of possible ozonolysis products. The formation of long-lived organic nitrates is significant as they may contribute to the long-range transport of $\mathrm{NO}_{\mathrm{x}}$ and the unexplained burden of organic nitrates in the free troposphere (Horowitz et al., 2007; Perring et al., 2009a). There are also large uncertainties on the yield and fate of organic nitrates formed at night from isoprene $+\mathrm{NO}_{3}$ chemistry (Horowitz et al., 2007; Brown et al., 2009).

The representation of $\mathrm{NO}_{\mathrm{x}}$ recycling (Reaction (R15)), segregation (Reaction (R16)) and depositional loss (Reaction (R17)) vary considerably across models. This is known to contribute to differences in simulated ozone (Stevenson et al., 2006; Wu et al., 2007; Jacob and Winner, 2009). For instance, in the standard release of GEOS-Chem, isoprene nitrates are assumed to deposit readily, such that they behave like a terminal sink for $\mathrm{NO}_{\mathrm{x}}$ much like nitric acid in the boundary layer (Fiore et al., 2005). In MOZART 
(Horowitz et al., 2007), isoprene nitrates are short-lived and a large fraction is oxidized by ozone and $\mathrm{OH}$ to yield secondgeneration organic nitrates that are then solely deposited.

To determine the impact of isoprene photochemistry, the relative importance of Reactions (R2), (R3) (R4) and (R5) must be known. It remains, however, very uncertain. In particular the fate of $\mathrm{ISOPO}_{2}$ depends critically on:

1. The rate of the reaction of $\mathrm{RO}_{2}$ with $\mathrm{HO}_{2}$. GEOSChem and MOZART assume that the rate of $\mathrm{RO}_{2}+\mathrm{HO}_{2}$ is independent of $\mathrm{R}$ (for $n(C)>2$ ) with $k_{\mathrm{HO}_{2}}=7.4 \times$ $10^{-13} \exp (700 / \mathrm{T})$ (Horowitz et al., 1998, 2007). Kinetics studies suggest, however, that the rate of $\mathrm{RO}_{2}+\mathrm{HO}_{2}$ increases with the size of the molecule. The expression derived by Saunders et al. (2003), $k_{\mathrm{HO}_{2}}^{\prime}=2.91 \times$ $10^{-13} \exp (1300 / \mathrm{T})(1-\exp (-0.245 n(C)))$, is in good agreement with the rate measured by Boyd et al. (2003) for $\mathrm{ISOPO}_{2}$. For isoprene at $298 \mathrm{~K}, k_{\mathrm{HO}_{2}}^{\prime} / k_{\mathrm{HO}_{2}} \sim 2$.

2. The isoprene emission inventory. Compared with MEGAN, the GEIA emissions inventory (Guenther et al., 1995) is characterized by higher isoprene emissions in the northern mid-latitudes, which favor the reaction of isoprene peroxy radicals with NO. Using the GEIA inventory and $k_{\mathrm{HO}_{2}}$, Paulot et al. (2009b) found the fate of isoprene peroxy radicals to be dominated by their reaction with NO.

3. The isomerization rate of isoprene peroxy radicals. The rate derived by Crounse et al. (2011) is significantly slower than the theoretical rate derived by Peeters et al. (2009). It follows that the overall importance of the isomerization is much smaller than previous estimates (e.g., Peeters and Müller, 2010).

In this study, we focus on the regions located between $15^{\circ} \mathrm{S}$ and $7^{\circ} \mathrm{N}$ (Fig. 1) where more than $50 \%$ of the global terrestrial isoprene emissions are located. These estimates remain uncertain (Guenther et al., 2006) as (a) bottom-up estimates are derived from ground studies that are too sparse to capture the diversity of plants in the rain forest, and (b) topdown estimates using satellite measurements of formaldehyde (Palmer et al., 2003; Barkley et al., 2008) rely on chemical mechanisms that are known to poorly represent the photochemistry under high biogenics and low $\mathrm{NO}_{\mathrm{x}}$ conditions (e.g., Lelieveld et al., 2008; Stone et al., 2010). In particular, the yield of formaldehyde from isoprene oxidation under these conditions is ill-defined.

The ratio between emitted isoprene and $\mathrm{NO}_{\mathrm{x}}$ exhibits a strong seasonality that is primarily driven by $\mathrm{NO}_{\mathrm{x}}$ emissions from biomass burning (Fig. S1). This is in contrast to the Northern mid latitudes where this ratio is driven by the seasonality of isoprene emissions. The ratio of isoprene to $\mathrm{NO}_{\mathrm{x}}$ emissions spans a very wide range from less than 10 in the peak biomass burning season in Africa and Southeast Asia to more than 100 outside the biomass burning season in South America. In the following, we take advantage of the diversity of chemical regimes resulting from the very broad range of $\mathrm{NO}_{\mathrm{x}}$-to-isoprene ratios to examine how the impact of isoprene photooxidation on $\mathrm{O}_{\mathrm{x}}$ is modulated by local photochemical conditions. In Sect. 2 , we briefly describe the model and its adjoint. In Sect. 3.1, we detail the treatment of isoprene chemistry used in our reference simulation that is used as a starting point for the forward sensitivity simulations (Sect. 3.2.1) and the adjoint sensitivity simulations (Sect. 3.2.2). We then discuss the different processes that control the impact of the isoprene photochemical cascade at the regional scale (Sect. 4.1), far from isoprene sources (Sect. 4.2) and immediately downwind of large isoprene sources (Sect. 4.3). Finally, we conclude by presenting some avenues that may help tease out these different processes and improve their representations in chemical transport models (Sect. 4.4).

\section{Model description}

We use the GEOS-Chem global 3-D chemical transport model v8.2.1 (Bey et al., 2001, www.geos-chem.org) and its adjoint (Henze et al., 2007). The model is driven by the GEOS-5 assimilated meteorology from the NASA Goddard Earth Observing System. Here the resolution of the model is $4^{\circ} \times 5^{\circ}$ and 47 vertical layers. The reported results correspond to the period spanning June 2006 to May 2007 after a one and a half year spin-up. Isoprene emissions are calculated using MEGANv2.0 (Guenther et al., 2006; Millet et al., 2008). Anthropogenic emissions of $\mathrm{NO}_{\mathrm{x}}$ are calculated using the EDGAR v3.2 inventory scaled to the model run year according to fossil fuel usage (Olivier and Berdowski, 2001). $\mathrm{NO}_{\mathrm{x}}$ is also emitted from biomass burning (from GFED2 inventory, Randerson et al., 2006), soil (Yienger and Levy, 1995) and lightning (Price et al., 1997; Wang et al., 1998; Sauvage et al., 2007a). Dry deposition is calculated using a resistance-in-series model (Wesely, 1989; Wang et al., 1998). Wet deposition is calculated following the approach presented by Mari et al. (2000) and Jacob et al. (2000). Emissions and dry deposition are uniformly distributed in the planetary boundary layer.

Isoprene nitrate photochemistry is represented here using three surrogates: $\mathrm{ING}_{0}, \mathrm{ING}_{1}$ and $\mathrm{ING}_{2}$ (Table 1 ). $\mathrm{ING}_{0}$ represents first-generation nitrates formed from isoprene photooxidation during day and nighttime. $\mathrm{ING}_{0}$ retains a double bond, such that it is rapidly oxidized by $\mathrm{OH}(k(298 \mathrm{~K})=$ $4.6 \times 10^{-11} \mathrm{~cm}^{3} \mathrm{molec}^{-1} \mathrm{~s}^{-1}$, Reaction (R6)) and ozone $\left(k(298 \mathrm{~K})=9.5 \times 10^{-17} \mathrm{~cm}^{3} \mathrm{molec}^{-1} \mathrm{~s}^{-1}\right.$, Reactions (R9) and (R10)), consistent with laboratory observations (Paulot et al., 2011; Lockwood et al., 2010). For simplicity, the oxidation of $\mathrm{ING}_{0}$ by $\mathrm{OH}$ and ozone is assumed to yield the same products. $\mathrm{ING}_{1}$ and $\mathrm{ING}_{2}$ are both second-generation organic nitrates. $\mathrm{ING}_{1}$ represents nitrates from methacrolein (MACR), methylvinylketone (MVK) and other hydroxycarbonyls formed from isoprene photooxidation (e.g., HC5 and 


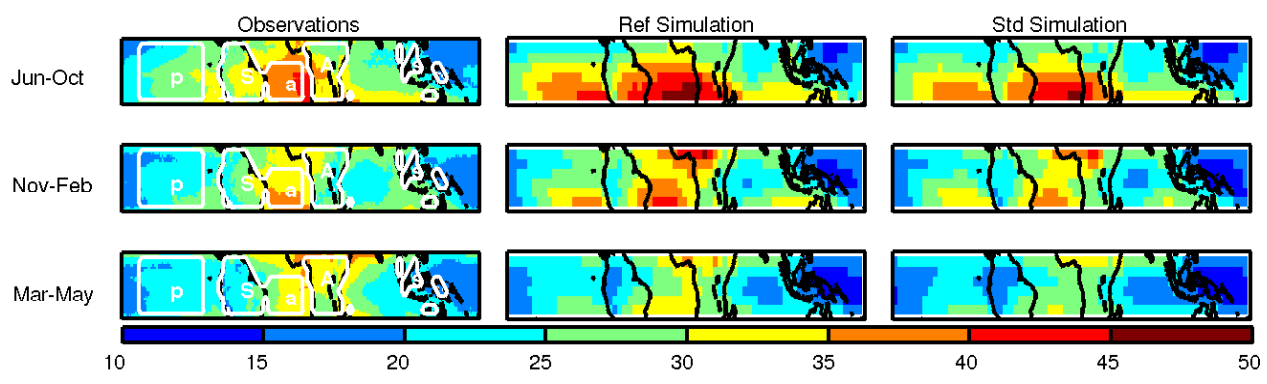

Fig. 1. OMI/MLS tropospheric column ozone in Dobson units (Ziemke et al., 2006) compared with simulated tropospheric column ozone in the new reference simulation (cf. Sect. 3.1) and in a standard simulation where $\mathrm{ING}_{0}$ is a terminal sink of $\mathrm{NO}_{\mathrm{x}}$. The different geographical regions used in this study are denoted by white contours. The tropical region extends from $15^{\circ} \mathrm{S}$ to $7^{\circ} \mathrm{N}$. Top row: June $2006-\mathrm{October} 2006$, middle row: November 2006-February 2007, bottom row: March 2007-May 2007.

$\mathrm{ING}_{0}$, Paulot et al., 2009a). $\mathrm{ING}_{1}$ is assumed to react rapidly with $\mathrm{OH}\left(k_{\mathrm{OH}}(298 \mathrm{~K})=8 \times 10^{-12} \mathrm{~cm}^{3} \mathrm{molec}^{-1} \mathrm{~s}^{-1}\right.$, Reaction (R12)), since it represents compounds that generally feature an aldehyde group. Lacking a double bond, $\mathrm{ING}_{1}$ does not react with ozone. $\mathrm{ING}_{0}$ photooxidation also yields $\mathrm{ING}_{2}$. This species represents the formation of long-lived nitrates and its oxidation by $\mathrm{OH}\left(k_{\mathrm{OH}}=4.0 \times 10^{-13} \mathrm{~cm}^{3} \mathrm{molec}^{-1} \mathrm{~s}^{-1}\right.$, Zhu et al. (1991), Reaction (R13)) and photolysis (Jenkin et al. (1997); Roberts and Fajer (1989), Reaction (R14)) are derived from propanone nitrate. Wet and dry deposition of $\mathrm{ING}_{0}, \mathrm{ING}_{1}$ and $\mathrm{ING}_{2}$ are treated as terminal losses of $\mathrm{NO}_{\mathrm{x}}$. In the following, we will use the notation ING to denote $\mathrm{ING}_{0}+\mathrm{ING}_{1}+\mathrm{ING}_{2}$.

Besides the representation of the isoprene nitrates, the standard GEOS-Chem mechanism has been modified to incorporate the isomerization of the isoprene peroxy radicals (Crounse et al., 2011), the formation of the isoprene epoxide (Paulot et al., 2009b) as well as the carbon dependence of the reaction of $\mathrm{HO}_{2}$ with peroxy radicals (Saunders et al., 2003). These changes are detailed in Table 1.

\section{Simulations}

ING photochemistry can affect ozone production in two different ways: (a) their formation depletes $\mathrm{NO}_{\mathrm{x}}$, diminishing local ozone production and the concentration of $\mathrm{OH}$, and (b) their photooxidation releases $\mathrm{NO}_{\mathrm{x}}$, which, conversely, promotes local photochemistry and ozone formation. If ING lifetime is short and $\mathrm{NO}_{\mathrm{x}}$ is recycled efficiently, (a) and (b) largely compensate each other and the regional effect of ING is reduced. Conversely, if ING lifetime is long, their formation and transport modulate $\mathrm{NO}_{\mathrm{x}}$ concentration and thus ozone production in both local and remote regions.

Forward sensitivity simulations are used to explore the local and regional impacts of the representation of isoprene nitrate photochemistry. The long lifetime of ozone makes it difficult to ascribe large-scale changes in ozone to either (a), (b) or the transport of ozone using forward simulations. We use adjoint modeling to evaluate the large scale impact of the isoprene photochemical cascade, as it allows us to explore the sensitivity of a given function of the model outputs $(\mathcal{J})$ to small perturbations of many parameters (Giering and Kaminski, 1998),

\subsection{Reference simulation}

Both adjoint and forward sensitivity simulations use the same reference simulation. We set the yield of the isoprene nitrate $(\mathrm{Y})$ to $10 \%$, the recycling to $50 \%(\alpha)$. Henry's constants are taken from Ito et al. (2007) for $\mathrm{ING}_{0}$ and $\mathrm{ING}_{1}$ $\left(H=1.7 \times 10^{4} \mathrm{Matm}\right)$ and from Sander (1999) for $\mathrm{ING}_{2}$ $\left(H=10^{3} \mathrm{Matm}\right)$. The oxidation of isoprene in this simulation is dominated by $\mathrm{OH}$ in every region $(\sim 85 \%$ globally, Fig. 2). The lifetime of isoprene can exceed six hours over South America, because of very low $\mathrm{OH}$. This long lifetime results in the efficient transport of isoprene to the free troposphere through convection, such that $20 \%$ of isoprene is oxidized outside of the boundary layer (Fig. S2). In the tropics, isoprene peroxy radicals react primarily with $\mathrm{HO}_{2}(\sim 60 \%)$. Reaction with NO and isomerization (Peeters et al., 2009; Crounse et al., 2011) accounts for $\sim 25 \%$ and $10 \%$ of isoprene peroxy radical fate, respectively.

The fate of isoprene peroxy radicals has important consequences regarding the yield of its second- and thirdgeneration products. In the reference simulation, we find that IEPOX, the epoxide formed from the oxidation of isoprene hydroxyhydroperoxide (ISOPOOH) has a global yield of $\sim 32 \%$, significantly larger than that simulated by Paulot et al. (2009a) using $k_{\mathrm{HO}_{2}}^{\mathrm{I}}$, the GEIA emission inventory and neglecting isomerization (Fig. 2). This has important implications for the representation of secondary organic aerosol from isoprene photooxidation under low $\mathrm{NO}_{\mathrm{x}}$ conditions (Surratt et al., 2010; Froyd et al., 2010). The chemical representation of the isoprene photochemical cascade also affects the use of the formaldehyde total column to estimate isoprene emissions in tropical regions as the yield of formaldehyde from the photooxidation of HPALD and ISOPOOH, which together account for $\sim 65 \%-75 \%$ of 


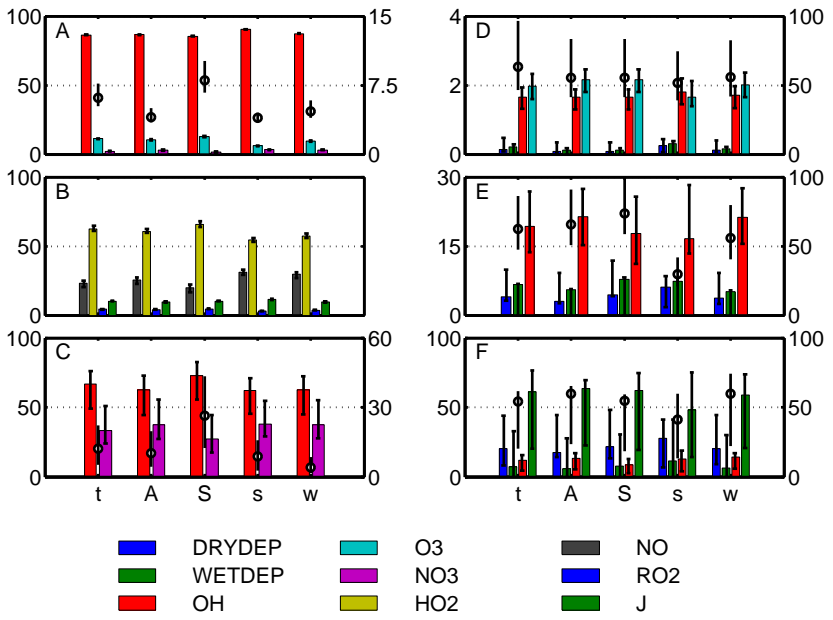

Fig. 2. Overview of the isoprene photochemical cascade (thick color bars) for the reference simulation in different regions (Tropics (t), Africa (A), South America (S), Southeast Asia (s) and World (w)). Branching ratios for the reference run (in percent) are indicated by bars for isoprene oxidation (A, left axis), isoprene peroxy radical fate ( $\mathrm{B}$, left axis), isoprene nitrate sources ( $\mathrm{C}$, left axis), $\mathrm{ING}_{0}$ fate (D, right axis), $\mathrm{ING}_{1}$ fate (E, right axis), $\mathrm{ING}_{2}$ fate $(\mathrm{F}$, right axis). Black open circles indicate the lifetime (in hours) of isoprene (A, right axis), $\mathrm{ING}_{0}\left(\mathrm{D}\right.$, left axis), $\mathrm{ING}_{1}$ (E, left axis) and $\mathrm{ING}_{2}$ (F, left axis), and the fractional loss of $\mathrm{NO}_{\mathrm{x}}$ caused by isoprene nitrate chemistry, $\mathcal{D}_{\mathrm{ING}} / \mathcal{L}_{\mathrm{NO}_{\mathrm{x}}}(\mathrm{C}$, right axis in $\%)$. The extent of the error bars represents the minimum and maximum values calculated using the different representations of isoprene nitrate chemistry. $\mathrm{J}$ designates the isomerization of isoprene peroxy radical (B, Peeters et al. (2009)) or the photolysis of $\mathrm{ING}_{2}(\mathrm{~F})$.

isoprene photooxidation in the tropics, is not known (Palmer et al., 2003; Barkley et al., 2008).

$\mathrm{ING}_{0}$ sources are dominated by $\mathrm{OH} / \mathrm{NO}$ chemistry (Fig. 2). As noted by Horowitz et al. (2007) and Brown et al. (2009), however, nocturnal formation of organic nitrates (from $\mathrm{NO}_{3}$ chemistry) can be a significant source of reactive organic nitrates. $\mathrm{ING}_{0}$ loss is dominated by photooxidation, consistent with Ito et al. (2007). The mean photochemical lifetime of $\mathrm{ING}_{0}$ is shorter than that of isoprene primarily because the formation of $\mathrm{ING}_{0}$ is favored by higher concentrations of $\mathrm{NO}$, which correlate with higher $\mathrm{OH}$ and ozone. Photochemical sinks of $\mathrm{ING}_{0}$ are dominated by ozone (Fig. 2). This reflects both the short atmospheric lifetime of $\mathrm{ING}_{0}$ with respect to ozone (Lockwood et al., 2010) and the importance of nocturnal sources of $\mathrm{ING}_{0}$ when $\mathrm{OH}$ oxidation is negligible. Because of its short atmospheric lifetime, the impact of $\mathrm{ING}_{0}$ on the transport of reactive nitrogen to the upper troposphere and to oceanic basins is very limited, suggesting the fraction of $\mathrm{NO}_{\mathrm{x}}$ recycled from $\mathrm{ING}_{0}$ photooxidation, as well as the fate of $\mathrm{ING}_{1}$ and $\mathrm{ING}_{2}$, are essential for assessing the overall effect of ING photochemistry.

Accounting for the photochemistry of isoprene nitrates results in an increase of $\sim 5 \mathrm{DU}$ in tropospheric ozone down- wind of continents compared to the standard GEOS-Chem simulations that treats isoprene nitrates as terminal $\mathrm{NO}_{\mathrm{x}}$ sinks (Fig. 1). The general seasonal and spatial patterns are in reasonable agreements with OMI-MLS measurements (Ziemke et al., 2006).

\subsection{Sensitivity simulations}

\subsubsection{Forward sensitivity simulations}

To assess the effect of different representations of isoprene nitrate photochemistry, we carry out 27 simulations that span three different isoprene nitrates yields $(\mathrm{Y}=0.05,0.10,0.15$ - Reaction (R3)), three different $\mathrm{NO}_{\mathrm{x}}$ recycling efficiency $(\alpha=0,0.5,1)$ from the reaction of $\mathrm{ING}_{0}$ with ozone (Reactions (R9) and (R10)) and OH/NO-NO 3 (Reactions (R6), (R7) and (R8)), and three different wet and dry deposition of $\mathrm{ING}_{0}, \mathrm{ING}_{1}$ and $\mathrm{ING}_{2}$. The deposition rate of INGs is modified by adjusting their associated Henry's constants. The effect of model resolution is not investigated. Ito et al. (2009) have shown that the optimal representation of isoprene nitrates may depend on the grid resolution: coarser grid results in greater dilution of $\mathrm{NO}_{\mathrm{x}}$ emissions increasing the simulated OPE (Valin et al., 2011). However, the different mechanisms identified in this study should operate regardless of the resolution though their relative magnitude may change. We expect this artifact to be most severe in regions with high biomass burning. Outside of these periods, when the sensitivity to isoprene nitrate chemistry is greatest, $\mathrm{NO}_{\mathrm{x}}$ emissions are low over most isoprene source regions with an important contribution of soil $\mathrm{NO}_{\mathrm{x}}$, resulting in limited segregation between $\mathrm{NO}_{\mathrm{x}}$ and isoprene source. The impact of resolution is expected to be reduced on the synoptic scale (Fiore et al., 2003).

In the base case, Henry's constants are taken from Ito et al. (2007) for $\mathrm{ING}_{0}$ and $\mathrm{ING}_{1}\left(H=1.7 \times 10^{4} \mathrm{M} \mathrm{atm}^{-1}\right)$ and from Sander (1999) for $\mathrm{ING}_{2}\left(H=10^{3} \mathrm{Matm}^{-1}\right)$. In the slow deposition case, INGs are deposited like PAN $(H=$ $3.6 \mathrm{Matm}^{-1}$, no wet deposition) while in the fast deposition case, they are all assumed to behave like nitric acid $\left(H=1 \times 10^{14} \mathrm{M} \mathrm{atm}^{-1}\right)$. This range of parameters captures the uncertainty in the representation of isoprene nitrates in chemical models.

In addition, one simulation is carried out where the yield of $\mathrm{ING}_{0}$ (Reaction (R3)) is set to $0 \%$. In another simulation, the yield $\mathrm{ING}_{0}$ is set to $10 \%$ (Reaction (R3)) but $\mathrm{ING}_{0}$ does not undergo any additional photochemistry. The later simulation is similar to the treatment of $\mathrm{ING}_{0}$ in the default GEOS-Chem chemical mechanism.

Modifying the treatment of isoprene nitrate chemistry has little impact on the relative importance of the oxidation channels of isoprene, because variation in ozone and $\mathrm{OH}$ mixing ratios are well correlated. However the lifetime of isoprene is strongly impacted by the representation of isoprene nitrate chemistry with variations exceeding $\sim \pm 20 \%$ across 


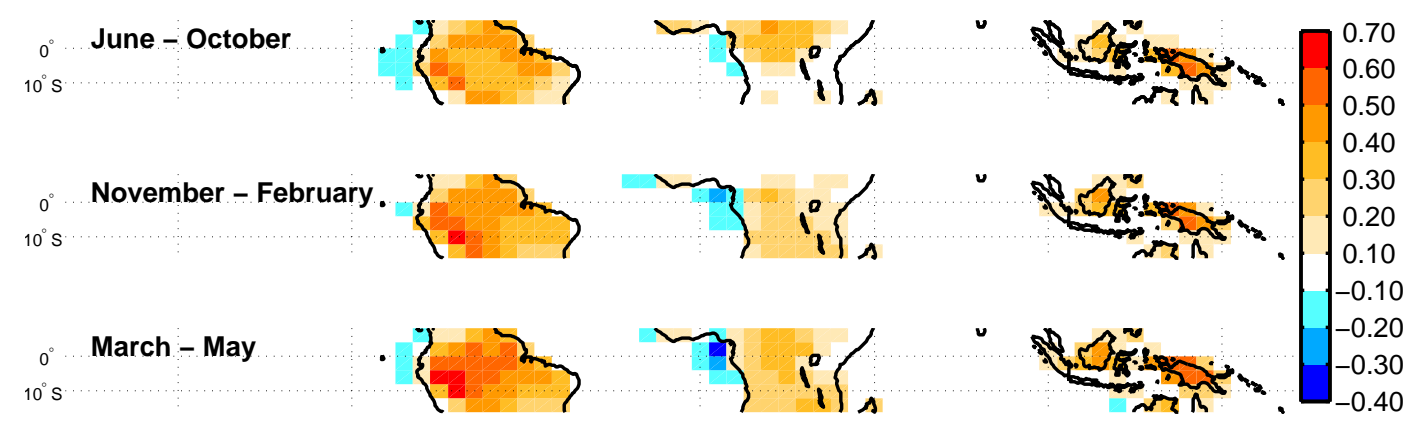

Fig. 3. Isoprene nitrate chemistry significantly affects the budget of $\mathrm{NO}_{\mathrm{x}}$ in the tropics. Positive numbers represent the fraction of the net chemical loss of $\mathrm{NO}_{\mathrm{x}}\left(\mathcal{L}_{\mathrm{NO}_{\mathrm{x}}}\right)$ accounted for by isoprene nitrate photochemistry $\left(\mathcal{D}_{\mathrm{ING}}>0\right)$ in the tropospheric column. Negative numbers denote the fraction of the net chemical source of $\mathrm{NO}_{\mathrm{x}}$ accounted for by isoprene nitrate photochemistry $\left(\mathcal{D}_{\mathrm{ING}}<0\right)$ in the tropospheric column.

the different simulations (Fig. 2). The largest changes are found over South America, where NO is very low.

The branching between night and day formation of $\mathrm{ING}_{0}$ depends on the assumed yield of isoprene nitrates (Y, Reaction (R3)). For an organic nitrate yield of $5 \%$ from $\mathrm{OH} / \mathrm{NO}$ chemistry, $\mathrm{NO}_{3}$ chemistry (Reaction (R11)) becomes the primary source of $\mathrm{ING}_{0}$ consistent with the conclusions from Horowitz et al. (2007) (Fig. 2). Even when $\mathrm{ING}_{0}$ is assumed to deposit as fast as nitric acid, its fate remains dominated by photooxidation reflecting its short photochemical lifetime. Because of their slower photooxidative sinks, $\mathrm{ING}_{1}$ and $\mathrm{ING}_{2}$ are much more sensitive to the treatment of deposition. Better constraints on the relative importance of photochemical and depositional sinks are especially critical for $\mathrm{ING}_{2}$ since it contributes significantly to the transport of $\mathrm{NO}_{\mathrm{x}}$. From this analysis, it is clear that the treatment of $\mathrm{ING}_{0}$ as a terminal sink of $\mathrm{NO}_{\mathrm{x}}$ (e.g., the assumption that they fully deposit) in the GEOS-Chem standard simulations cannot be reconciled with laboratory data presented by Lockwood et al. (2010) and Paulot et al. (2009a).

\subsubsection{Adjoint sensitivity simulations}

The adjoint of GEOS-Chem has been primarily used in inversion problems to improve emissions inventories (Henze et al., 2009; Kopacz et al., 2010). It was recently used by Kopacz et al. (2011) to constrain the sources of black carbon in the Himalayas and Tibetan Plateau and by Zhang et al. (2009) to investigate the impact of intercontinental transport on ozone pollution on the west coast of the United States.

Here we use the adjoint of GEOS-Chem to explore the sensitivity of ozone and $\mathrm{NO}_{\mathrm{x}}$ to some of the photochemical processes controlling the isoprene photochemical cascade: the emissions of isoprene and $\mathrm{NO}_{\mathrm{x}}, \mathrm{Y}$ and $\alpha$. Similar adjoint approaches have been used previously to investigate the chemical processes controlling ozone pollution in urban settings (Menut et al., 2000; Vautard et al., 2000; Schmidt and Martin, 2003; Martien et al., 2006). Here, the cost function $\mathcal{J}$ is defined as either the mean tropospheric ozone or $\mathrm{NO}_{\mathrm{x}}$ mixing ratio (in ppbv). We consider three time periods: July 2006 to October 2006 (high biomass burning in all tropical continental regions, Fig. S1); December 2006 to February 2007 (high biomass burning in Northern Africa, low biomass burning over South America and Southeast Asia); April 2007 to May 2007 (low biomass burning for all tropical regions); and four geographical regions (Fig. 1) that are largely isolated from transport of ozone from Northern midlatitudes. For each time period, the model is run for one additional buffer month in order to limit the bias for long-range influence and initial conditions (Figs. S3 and S4). For instance, the sensitivity of a cost function defined over the period April to May is calculated by running the adjoint back through March. We define ${ }_{\mathrm{X}}^{\mathrm{R}_{1}} \hat{s}_{\mathrm{B}}^{\mathrm{A}}$ as the normalized sensitivity of $A$ in region $R_{1}$ to changes in $\mathrm{B}$ in the model box $\mathrm{X}$ located at latitude lat, longitude lon, and altitude z, i.e., $\frac{B(X)}{\mathcal{J}} \frac{\partial \mathcal{J}}{\partial B(X)}$ where $\mathcal{J}=\left.\bar{A}\right|_{R_{1}}$ and $\overline{(.)}$ designates the tropospheric mean. We define:

$$
{ }_{\mathrm{R}}^{\mathrm{R}_{1}} \mathcal{S}_{\mathrm{B}}^{\mathrm{A}}=\sum_{\text {lat } \in R_{2} ; z \leq z t} \frac{{ }_{\mathrm{X}}^{\mathrm{R}} \hat{s}_{\mathrm{B}}^{\mathrm{A}}}{\Delta_{\text {lon }}(\mathrm{X})}
$$

where $z_{t}$ is the tropopause altitude and $\Delta_{\mathrm{lon}}(\mathrm{X})=5^{\circ}$ is the longitudinal resolution of the model. Acronyms used for $\mathrm{R}_{1}$ and $\mathrm{R}_{2}$ are listed in Table A. For instance, ${ }_{\mathrm{A}}^{\mathrm{a}} \mathcal{S}_{\mathrm{OH}+\mathrm{ING}_{0}}^{\mathrm{O}_{3}}$ refers to the normalized sensitivity of Atlantic mean tropospheric ozone (in $\%$ per $^{\circ}$ longitude) to the rate of oxidation of $\mathrm{ING}_{0}$ by $\mathrm{OH}$ over Africa. We will use the notation ${ }^{\mathrm{R}_{1}} \mathcal{S}_{\mathrm{B}}^{\mathrm{A}}$ to refer to zonal changes in the sensitivity of $A$ in region $R_{1}$ to $B$.

\section{Discussion}

The modeled tropical ozone over continental regions is very sensitive to the treatment of ING photochemistry (Figs. 1 and S5). Over continental regions, ozone can vary by as much as $\pm 20 \%$ from the reference simulation as a result of changes in the representation of ING photochemistry. Changes in 
ozone are not limited to continental regions with high isoprene emissions. Downwind of Africa and South America, for instance, the Atlantic and Pacific basins exhibit a sensitivity to ING chemistry similar to continental regions. Ozone over remote oceanic regions is also found to be affected by isoprene photochemistry.

$\mathrm{NO}_{\mathrm{x}}$ concentrations play a critical role in modulating ozone production. In order to rationalize the simulated sensitivity of ozone to changes in the representation of isoprene nitrates, we thus define the local net removal of $\mathrm{NO}_{\mathrm{x}}$ by isoprene nitrate chemistry as:

$$
\mathcal{D}_{\mathrm{ING}}=\mathcal{P}_{\mathrm{ING}_{0}}+\mathcal{P}_{\mathrm{ING}_{1}}^{\star}-\mathcal{L}_{\mathrm{ING}_{1}}-\mathcal{L}_{\mathrm{ING}_{2}}-\alpha \times \mathcal{L}_{\mathrm{ING}_{0}}
$$

where $\mathcal{P}_{\mathrm{ING}_{0}}$ and $\mathcal{P}_{\mathrm{ING} 1}^{\star}$ are the photochemical sources of $\mathrm{ING}_{0}$ and $\mathrm{ING}_{1}$ (excluding the source from $\mathrm{ING}_{0}$ ); $\mathcal{L}_{\mathrm{ING}_{0}}$, $\mathcal{L}_{\mathrm{ING}_{1}}$ and $\mathcal{L}_{\mathrm{ING}_{2}}$ are the photochemical losses of $\mathrm{ING}_{0}$, $\mathrm{ING}_{1}$ and $\mathrm{ING}_{2}$. $\mathcal{D}_{\text {ING }}$ defines three regimes associated with different regions of the tropics (Fig. 3): the continents, where isoprene nitrate photochemistry results in $\mathrm{NO}_{\mathrm{x}}$ loss $\left(\mathcal{D}_{\mathrm{ING}}>\right.$ 0 ); the near-shore oceanic basins, where isoprene nitrate photochemistry contributes to $\mathrm{NO}_{\mathrm{x}}$ production $\left(\mathcal{D}_{\mathrm{ING}}<0\right)$; and the remote oceanic basins $\left(\mathcal{D}_{\mathrm{ING}} \sim 0\right)$.

In this section, we show that the impact of isoprene photochemistry on ozone in each of these regions reflect different mechanisms: modulation of $\mathrm{NO}_{\mathrm{x}}$ where $\mathcal{D}_{\mathrm{ING}}>0$, transport of ozone produced in the upper troposphere where $\mathcal{D}_{\mathrm{ING}} \sim 0$ and finally the competition between the transport of ozone and $\mathrm{NO}_{\mathrm{x}}$ where $\mathcal{D}_{\mathrm{ING}}<0$.

\section{1 $\mathrm{NO}_{\mathrm{x}}$ removal efficiency controls the impact of isoprene nitrates over tropical continental regions $\left(\mathcal{D}_{\text {ING }}>\mathbf{0}\right)$}

Over regions with high isoprene and low $\mathrm{NO}_{\mathrm{x}}$ emissions (e.g, South America, New Guinea), $\mathcal{D}_{\text {ING }}$ can account for up to $70 \%$ of $\mathrm{NO}_{\mathrm{x}}$ loss $\left(\mathcal{L}_{\mathrm{NO}_{\mathrm{x}}}\right)$. On continental scales, however, a large fraction of the $\mathrm{NO}_{\mathrm{x}}$ segregated in isoprene nitrates is cycled back to the atmosphere ( $61 \%$ for Africa, $48 \%$ for South America).

The sensitivity of $\mathrm{O}_{\mathrm{x}}$ production $\left(\mathcal{P}_{\mathrm{O}_{\mathrm{x}}}\right)$ to ING photochemistry is well correlated with its effect on $\mathcal{D}_{\text {ING }}$ (Fig. 4). It follows that very different representations of the ING chemistry can have comparable effects on continental $\mathcal{P}_{\mathrm{O}_{\mathrm{x}}}:\{\mathrm{Y}=$ $15 \%, \alpha=100 \%$, fast deposition $\},\{\mathrm{Y}=10 \%, \alpha=50 \%$, fast deposition $\},\{\mathrm{Y}=15 \%, \alpha=50 \%$, default deposition $\}$ yield similar $\mathcal{P}_{\mathrm{O}_{\mathrm{x}}}$ over South America. However, as the $\mathrm{NO}_{\mathrm{x}}$ loss mechanisms (export to oceanic basins and deposition) are different in each of these representations, they result in diverse predictions regarding nitrogen deposition and ozone formation downwind from continents, such that the need to accurately constrain ING photochemistry is not relaxed.

The sensitivity of $\mathcal{P}_{\mathrm{O}_{\mathrm{x}}}$ to $\mathcal{D}_{\mathrm{ING}}$ varies regionally and seasonally reflecting changes in the fraction of $\mathrm{NO}_{\mathrm{x}}$ lost through the isoprene nitrate chemistry (Fig. S6). Continental ozone is most sensitive to isoprene nitrate chemistry outside the

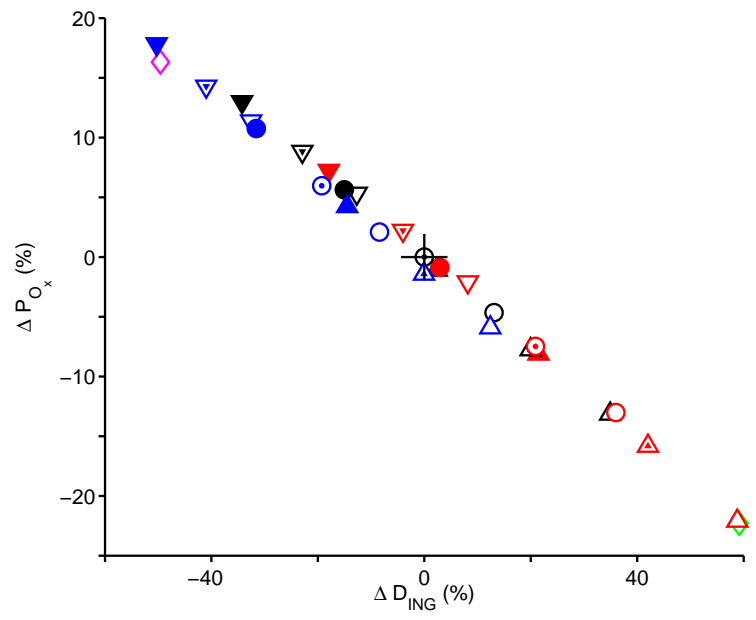

Fig. 4. The correlation between $\mathcal{D}_{\mathrm{ING}}$ and $\mathcal{P}_{\mathrm{O}_{\mathrm{x}}}$ on the regional scale (South America) across a large range of representations of ING chemistry suggests that the influence of ING chemistry on $\mathcal{P}_{\mathrm{O}_{\mathrm{x}}}$ is primarily controlled by its net impact on $\mathrm{NO}_{\mathrm{x}}$. Upwardpointing triangles/Circles/downward-pointing triangles denote different $I N G_{0}$ yields: $Y=5 \% / 10 \% / 15 \%$; red/black/blue colors refer to fast/medium/slow ING deposition; empty/half filled/filled symbols denote different $\mathrm{NO}_{\mathrm{x}}$ recycling from the photooxidation of $\mathrm{ING}_{0}: \alpha=0 / 50 / 100 \%$. The reference simulation is indicated by a vertical cross. The purple diamond indicates a simulation where the yield of $\mathrm{ING}_{0}$ from $\mathrm{ISOPO}_{2}+\mathrm{NO}$ is set to zero. The green diamond indicates a simulation where $\mathrm{ING}_{0}, \mathrm{ING}_{1}$ and $\mathrm{ING}_{2}$ have no photochemical sink (similar to the standard GEOS-Chem mechanism).

biomass burning seasons, when isoprene impact on $\mathcal{L}_{\mathrm{NO}_{\mathrm{x}}}$ is largest. Conversely, the representation of isoprene nitrate chemistry has little regional impact on ozone during the biomass burning period regardless of isoprene emissions. This difference can be understood through the seasonal variation of $\mathcal{D}_{\mathrm{ING}} / \mathcal{L}_{\mathrm{NO}_{\mathrm{x}}}$. While increasing the production of INGs, large emissions of $\mathrm{NO}_{\mathrm{x}}$ during the biomass burning season favor the production of $\mathrm{OH}$ and ozone such that the lifetime of INGs is reduced and their effect on the ozone budget is diminished. This effect is not captured when isoprene nitrates are assumed to be a terminal sink of $\mathrm{NO}_{\mathrm{x}}$ (i.e., independent of the photochemical conditions) such as in the standard GEOS-Chem mechanism (Fig. 1). The sensitivity to changes in isoprene or biomass burning emissions is thus expected to be different.

The adjoint sensitivity of tropical ozone to isoprene nitrate yield $\left({ }^{t} \mathcal{S}_{\mathrm{Y}}^{\mathrm{O}_{3}}\right)$ is negative everywhere (Fig. 5). This is consistent with the regional removal of $\mathrm{NO}_{\mathrm{x}}$ dominating the impact of isoprene nitrate photochemistry on ozone. Seasonal and regional variations in the sensitivity reflect those of $\mathcal{D}_{\mathrm{ING}} / \mathcal{L}_{\mathrm{NO}_{\mathrm{x}}}$, e.g., the sensitivity of tropical ozone to changes in the isoprene nitrate yield over Africa, ${ }_{\mathrm{A}}^{\mathrm{t}} \mathcal{S}_{\mathrm{Y}}^{\mathrm{O}_{3}}$, is $\sim 5$ times greater from April to May than from December to February. ${ }^{\mathrm{t}} \mathcal{S}_{\mathrm{Y}}^{\mathrm{O}_{3}}$ is significantly greater than ${ }^{\mathrm{t}} \mathcal{S}_{\mathrm{ISOP}+\mathrm{O} 3}^{\mathrm{O}_{3}}$, suggesting that 

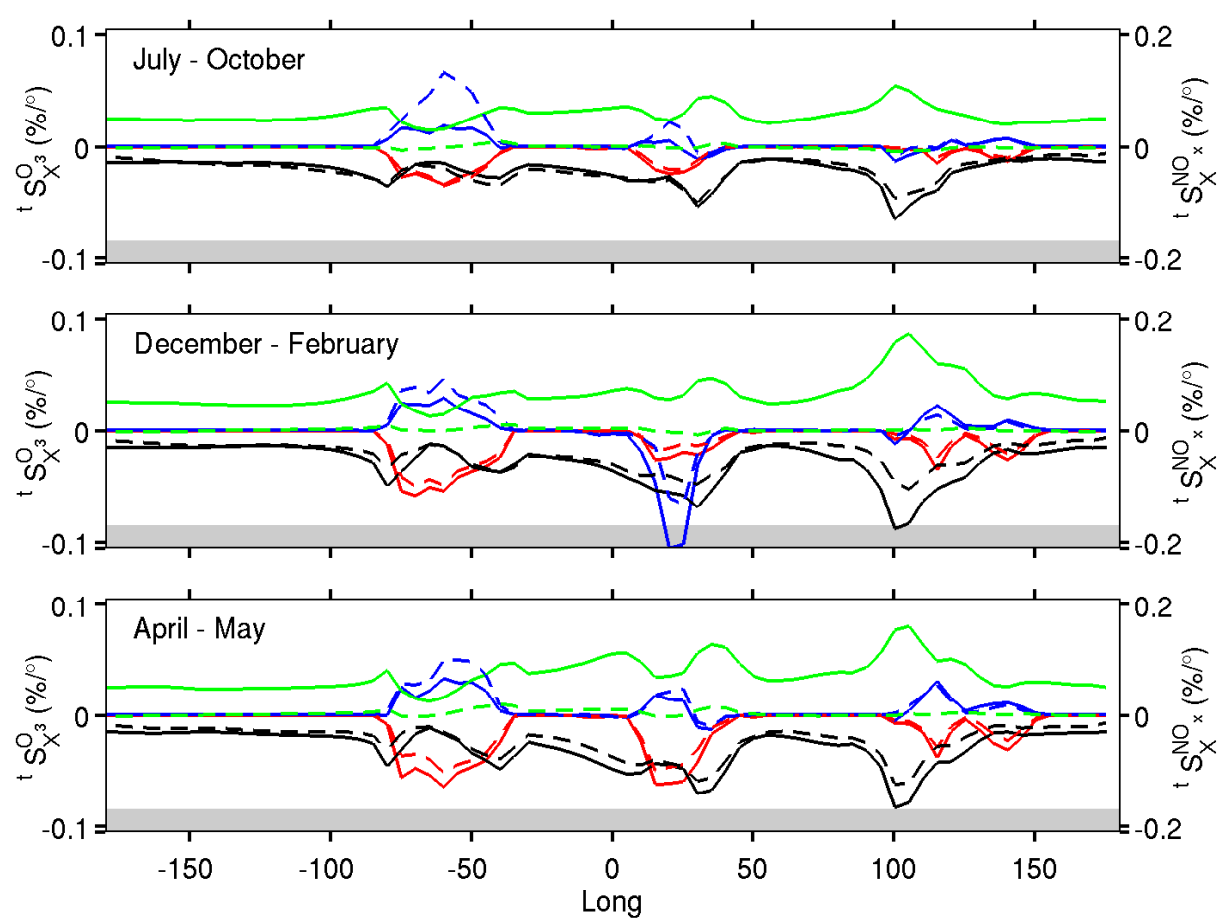

Fig. 5. Adjoint sensitivity of tropical ozone (solid lines) and $\mathrm{NO}_{\mathrm{x}}$ (dashed lines) to changes in the isoprene nitrate yield (red), the isoprene nitrate recycling (blue, $\times 5$ ), the loss rate of methane (green, $\mathrm{CH}_{4}+\mathrm{OH}$ ), the rate of $\mathrm{OH}+\mathrm{NO}_{2}($ black, $\times 0.5)$. For example, the mean sensitivity of tropospheric tropical ozone to methane oxidation from July to October is $\sim 0.028 \%$ per degree longitude (from $-15^{\circ} \mathrm{N}$ to $7^{\circ} \mathrm{N}$ ). Hence, a uniform increase of $1 \%$ of the oxidation rate of methane by $\mathrm{OH}$ is predicted to cause an increase in tropospheric tropical ozone of $\sim 0.1 \%$. In contrast, an increase of the isoprene nitrate yield (Y) by $1 \%$ would result in a decrease in ozone of $\sim 0.02 \%$. Increases in the absolute sensitivity of ozone to $\mathrm{NO}_{\mathrm{x}}$ losses from one season to another (e.g., over Africa from December-February to April-May) reflect changes in OPE. The grey shaded region denotes the region over which the cost functions are evaluated.

the segregation of $\mathrm{NO}_{\mathrm{x}}$ by isoprene nitrate is more effective at reducing ozone than its direct destruction by ISOP $+\mathrm{O}_{3}$ (Fig. S9).

The sensitivity of tropical ozone to the yield of the nitrate, $\mathrm{Y}$, can be compared to its sensitivity to methane oxidation (Fig. 5). ${ }^{\mathrm{t}} \mathcal{S}_{\mathrm{OH}+\mathrm{CH} 4}^{\mathrm{O}_{3}}$ is always positive and its zonal variations largely reflect the fraction of methylperoxy radicals reacting with NO (Jaeglé et al., 2001; Wennberg et al., 1998). As a result, ${ }^{t} \mathcal{S}_{\mathrm{OH}+\mathrm{CH}_{4}}$ is generally larger over continents, where $\mathrm{NO}$ emissions are concentrated. An important exception is South America where the oxidation of methane is limited by the low $\mathrm{OH}$ concentrations simulated by the model in low$\mathrm{NO}_{\mathrm{x}}$, high-biogenic environments.

Ozone is very sensitive to the formation rate of nitric acid $\left({ }^{t} \mathcal{S}_{\mathrm{OH}+\mathrm{NO}_{2}}\right.$ ), a major sink of $\mathrm{NO}_{\mathrm{x}}$ in much of the atmosphere, emphasizing the need for very accurate understanding of the reaction of $\mathrm{OH}$ with $\mathrm{NO}_{2}$ (Mollner et al., 2010). The production of both $\mathrm{ING}_{0}$ and nitric acid result in the loss of $\mathrm{NO}_{\mathrm{x}}$. As a result, ${ }^{t} \mathcal{S}_{\mathrm{OH}+\mathrm{NO}_{2}}$ and ${ }^{\mathrm{t}} \mathcal{S}_{\mathrm{Y}}^{\mathrm{O}_{3}}$ are negative throughout the tropics. Nitric acid formation is most efficient when the concentrations of $\mathrm{OH}$ and $\mathrm{NO}_{2}$ are elevated, i.e., over large $\mathrm{NO}_{\mathrm{x}}$ sources (biomass burning in Africa or anthropogenic and biomass burning in Java, Fig. 5). Unlike nitric acid, the pho- tochemical lifetime of $\mathrm{ING}_{0}$ is very short under these conditions and it is not an efficient sink of $\mathrm{NO}_{\mathrm{x}}$. However, under low $\mathrm{NO}_{\mathrm{x}}$ conditions and high isoprene emissions, $\mathrm{ING}_{0}$ photooxidation is limited and it behaves, at least locally, as an important sink of $\mathrm{NO}_{\mathrm{x}}$ (Fig. 3). It follows that ${ }^{t} \mathcal{S}_{\mathrm{OH}+\mathrm{NO} 2}^{\mathrm{O}_{3}}$ and ${ }^{t} \mathcal{S}_{\mathrm{Y}}^{\mathrm{O}_{3}}$ have opposite dependence on surface $\mathrm{NO}_{\mathrm{x}}$ conditions. This is supported by their seasonal variations over South America where ${ }_{\mathrm{S}}^{\mathrm{t}} \mathcal{S}_{\mathrm{OH}+\mathrm{NO} 2}^{\mathrm{O}_{3}}$ is greater than ${ }_{\mathrm{S}}^{\mathrm{t}} \mathcal{S}_{\mathrm{Y}}^{\mathrm{O}_{3}}$ during the biomass burning season $\left(\mathcal{D}_{\mathrm{ING}} / \mathcal{L}_{\mathrm{NO}_{\mathrm{x}}} \ll 1\right)$, but significantly lower outside the biomass burning seasons (Fig. 5). Seasonal variations are even greater in Africa where ${ }_{A}^{t} \mathcal{S}_{\mathrm{Y}}^{\mathrm{O}_{3}}$ is almost negligible from December to February (Fig. 5) when isoprene and biomass burning emissions are collocated (Fig. S1), but comparable to ${ }_{\mathrm{A}}^{\mathrm{t}} \mathcal{S}_{\mathrm{OH}+\mathrm{NO}_{2}}^{\mathrm{O}_{3}}$ from April to May. A similar mechanism may also explain the large contrast between Java, where ${ }_{\mathrm{S}}^{\mathrm{t}} \mathcal{S}_{\mathrm{Y}}^{\mathrm{O}_{3}} \ll_{\mathrm{S}}^{\mathrm{t}} \mathcal{S}_{\mathrm{OH}+\mathrm{NO}_{2}}^{\mathrm{O}_{3}}$ as a result of large anthropogenic activities, and the more pristine New Guinea where ${ }_{\mathrm{s}}^{\mathrm{t}} \mathcal{S}_{\mathrm{Y}}^{\mathrm{O}_{3}} \sim{ }_{\mathrm{s}}^{\mathrm{t}} \mathcal{S}_{\mathrm{OH}+\mathrm{NO}_{2}}^{\mathrm{O}_{3}}$.

${ }^{\mathrm{t}} \mathcal{S}_{\alpha}^{\mathrm{O}_{3}}$ suggests, however, that the impact of isoprene nitrate photochemistry (and more generally of isoprene photochemistry) on ozone is not restricted to the modulation of the local photochemistry. Indeed, while ${ }^{t} \mathcal{S}_{\alpha}^{\mathrm{O}_{3}}$ is generally 

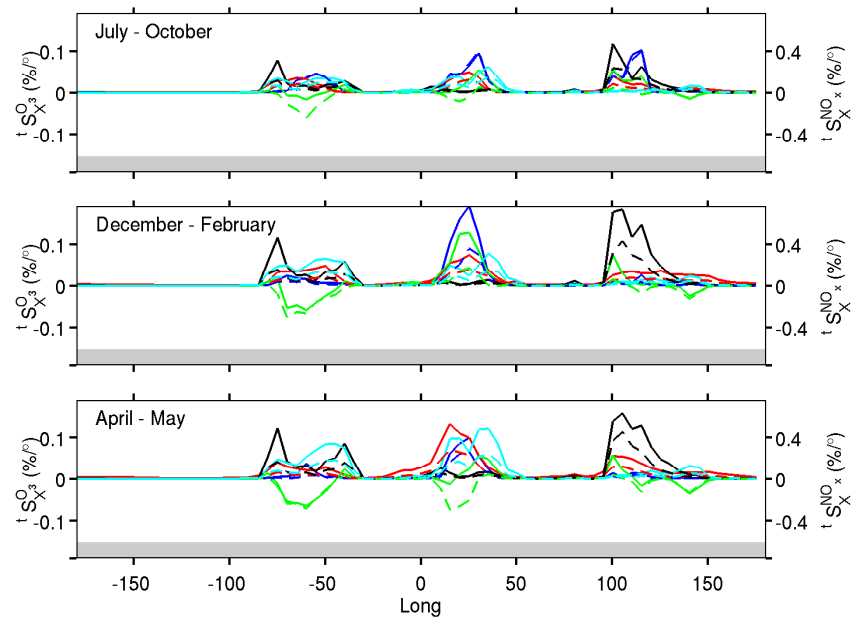

Fig. 6. Adjoint sensitivity of tropical ozone (solid lines) and $\mathrm{NO}_{\mathrm{x}}$ (dash lines) to changes in the emissions of isoprene (green), lightning $\mathrm{NO}_{\mathrm{x}}$ (red, $\times 0.5$ ), biomass burning $\mathrm{NO}_{\mathrm{x}}$ (blue), soil $\mathrm{NO}_{\mathrm{x}}$ (cyan) and anthropogenic $\mathrm{NO}_{\mathrm{x}}$ (black). The grey shaded region denotes the region over which the cost functions are evaluated.

positive, as would be expected from its impact on the local $\mathcal{D}_{\text {ING }}$ (Fig. 3), it becomes negative when isoprene emissions and biomass burning are collocated, e.g., in Africa from December to February. Similarly, the sensitivity of ozone to tropical emissions of isoprene $\left({ }^{\mathrm{t}} \mathcal{S}_{\mathrm{E}(\mathrm{ISOP})}^{\mathrm{O}_{3}}\right.$, Fig. 6) switches sign seasonally and regionally, unlike ${ }^{\mathrm{t}} \mathcal{S}_{\mathrm{E}\left(\mathrm{NO}_{\mathrm{x}}\right)}^{\mathrm{O}_{3}}$ that is always positive regardless of the source of $\mathrm{NO}_{\mathrm{x}}$. For instance, ${ }_{\mathrm{S}}^{\mathrm{t}} \mathcal{S}_{\mathrm{E}(\mathrm{ISOP})}^{\mathrm{O}_{3}}$ is positive during the biomass burning season (Fig. 6, July-October) and becomes negative as biomass burning emissions decrease (December-February and April-

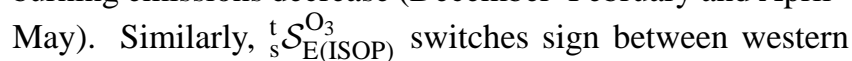
Southeast Asia and eastern Southeast Asia. The next two sections are devoted to unraveling the mechanisms that govern the interactions of the isoprene photochemical cascade with $\mathrm{O}_{\mathrm{x}}$ at the local and global scales.

\subsection{Long-range impact of isoprene photochemistry through transport to the upper troposphere $\left(D_{\text {ING }} \sim 0\right)$}

The contrast between the remote and local impacts of isoprene photooxidation on $\mathrm{O}_{\mathrm{x}}$ is directly illustrated by the large regional variability of ${ }^{\mathrm{S}} \mathcal{S}_{\mathrm{E}}^{\mathrm{O}_{3}}$ (ISOP) (Fig. 7). ${ }_{\mathrm{S}}^{\mathrm{S}} \mathcal{S}_{\mathrm{E} \text { (ISOP) }}^{\mathrm{O}_{3}}$ is negative and well correlated with ${ }_{\mathrm{S}}^{\mathrm{S}} \mathcal{S}_{\mathrm{E}(\mathrm{ISOP})}^{\mathrm{NO}_{\mathrm{x}}} \cdot{ }_{\mathrm{S}}^{\mathrm{S}} \mathcal{S}_{\mathrm{E}}^{\mathrm{O}_{3}}$ is minimum from December to May when $\mathcal{D}_{\text {ING }}$ contributes most to $\mathcal{L}_{\mathrm{NO}_{\mathrm{x}}}$. Unlike the regional effect of isoprene emissions on ozone, their long-range impact (dominated by Africa) is generally positive and not associated with a local production of ozone, as ${ }_{\mathrm{A}}^{\mathrm{S}} \mathcal{S}_{\mathrm{E} \text { (ISOP) }}^{\mathrm{NO}_{\mathrm{x}}}$ is very small.

Large-scale ozone enhancement fueled by isoprene photochemistry may impact the transport of ozone formed over
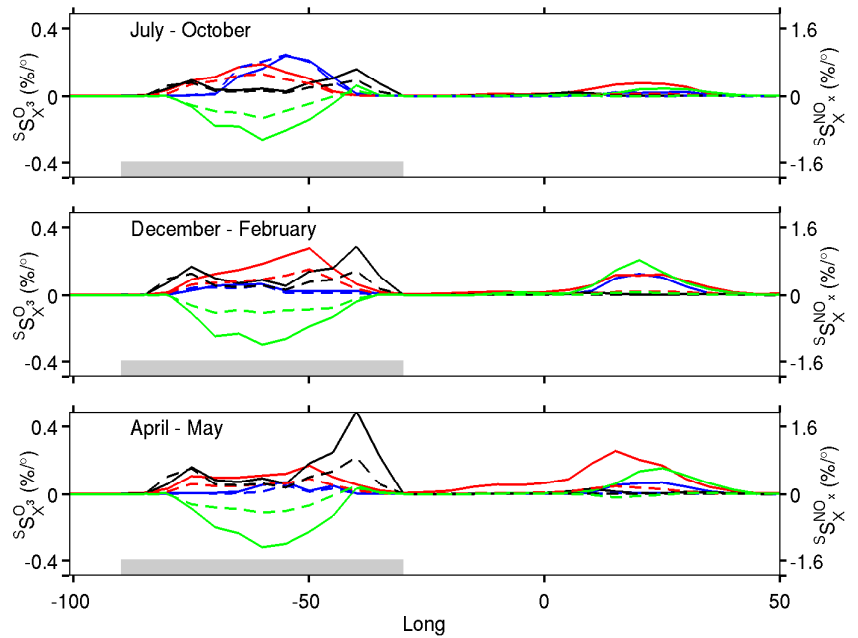

Fig. 7. Adjoint sensitivity of tropospheric ozone (solid lines) and $\mathrm{NO}_{\mathrm{x}}$ (dashed lines) over South America (shaded region) to changes in the emissions of isoprene (green), lightning $\mathrm{NO}_{\mathrm{x}}$ (red), biomass burning $\mathrm{NO}_{\mathrm{x}}$ (blue) and anthropogenic $\mathrm{NO}_{\mathrm{x}}$ (black).

continental regions, through the well-known "Atlanta" mechanism (Chameides et al., 1988), i.e., by the boundary layer oxidation of isoprene under elevated $\mathrm{NO}_{\mathrm{x}}$ conditions (e.g., from December to February in Africa). The spatial impact of this mechanism is usually limited in the midlatitudes because the lifetime of $\mathrm{O}_{\mathrm{x}}$ is relatively short in the boundary layer. In the tropics, however, efficient convective transport may allow $\mathrm{O}_{\mathrm{x}}$ to be carried to the free troposphere, where it can be advected over much larger spatial scales thanks to a significantly longer lifetime (Jacob et al., 1996).

The "Atlanta" mechanism does not, however, account for

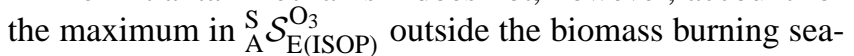
sons (April-May for Africa, Fig. 7). We propose that this reflects ozone production in the free troposphere driven by the transport of boundary layer isoprene and its photochemical products by convection. Observations of high concentrations of isoprene (up to $\sim 1 \mathrm{ppbv}$ ) and its photochemical products in the upper troposphere have been reported over Europe (Colomb et al., 2006; Stickler et al., 2006), Africa (Bechara et al., 2010; Murphy et al., 2010), and South America (Warneke et al., 2001). The model exhibits a very characteristic "C"-profile for isoprene in the tropics and a significant fraction of isoprene oxidation takes place outside the boundary layer ( $\sim 20 \%$ in the tropics, Fig. S2). In these conditions, the production of ozone is extremely efficient as (a) isoprene peroxy radicals react almost entirely with $\mathrm{NO}$, and (b) $\mathcal{D}_{\text {ING }} \sim 0$ as ING fate is almost entirely driven by $\mathrm{NO}_{\mathrm{x}^{-}}$ neutral photochemical reactions. The injections of reactive isoprene can have a very large impact on ozone production in particular if it is accompanied by emissions of $\mathrm{NO}_{\mathrm{x}}$ (e.g., from lightning) (Collins et al., 1999; Poisson et al., 2000; Jacob et al., 1996; Prather and Jacob, 1997). The formation of 

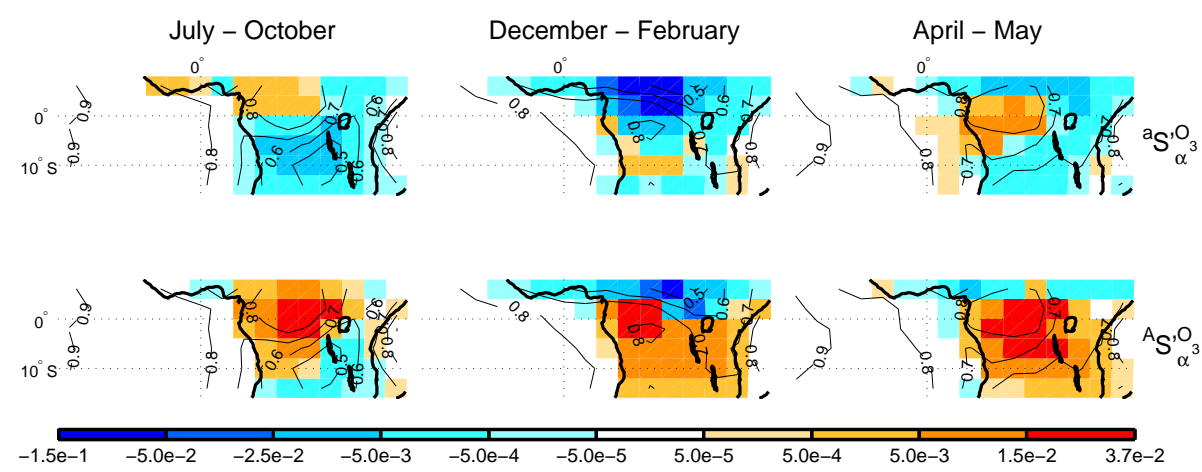

Fig. 8. Seasonal variations in the adjoint sensitivity of Atlantic (top row) and African (bottom row) ozone to the $\mathrm{NO}_{\mathrm{x}}$ recycling from $\mathrm{ING}_{0}$ photooxidation $(\alpha)$ summed from the surface to $p_{l}=500 \operatorname{mbar}\left(\mathrm{R}_{1} \mathcal{S}_{\alpha}^{\mathrm{O}_{3}}=\sum_{p>p_{l}} \mathrm{R}_{1} \hat{s}_{\alpha} \mathrm{O}_{3}\right.$ in $\%$ o $\left.{ }^{2}\right)$ ). Contours indicate the mean ratio between the loss of isoprene peroxy radicals through reaction with $\mathrm{HO}_{2}$ and the loss of isoprene peroxy radicals through reaction with $\mathrm{HO}_{2}$ and $\mathrm{NO}_{\text {. }}$

$\mathrm{NO}_{\mathrm{x}}$ reservoirs in the upper troposphere (e.g., PAN) further amplifies the impact of isoprene photochemistry on $\mathrm{NO}_{\mathrm{x}}$ by promoting the transport of $\mathrm{NO}_{\mathrm{x}}$ to remote regions (Poisson et al., 2000). Indeed, we find that an increase in the decomposition rate of PAN would generally result in a decrease of tropical ozone (Fig. S9). This mechanism would be consistent with the study of Aghedo et al. (2007), who reported that most of the production of ozone fueled by African emissions does not take place over the African continent, but rather downwind.

Ozone production in the free troposphere increases as the supply of isoprene and its photochemical products from the boundary layer increases, i.e., under low boundary layer oxidative conditions. Thus, the production of ozone in the upper troposphere is favored, somewhat paradoxically, by its destruction in the boundary layer. Since ozone is also transported to the upper troposphere, the net effect of the transport of isoprene to the upper troposphere depends on the relative magnitude of these two processes. Unlike Africa, where $\mathrm{NO}_{\mathrm{x}}$ is generally high enough such that isoprene photochemistry does not significantly depress $\mathcal{P}_{\mathrm{O}_{\mathrm{x}}}$ in the boundary layer, the segregation of $\mathrm{NO}_{\mathrm{x}}$ by isoprene nitrates in South America results in very low boundary layer $\mathrm{O}_{\mathrm{x}}$ (Fig. 7). The competition between the local destruction of ozone and its downwind production is reflected in the greater sensitivity of Pacific ozone to isoprene emissions from Africa compared to South America outside the biomass burning seasons (Fig. S7). Similarly, ${ }_{S} \mathcal{S}_{\mathrm{E}(\mathrm{ISOP})}^{\mathrm{O}_{3}}$ is generally negative, reflecting its impact on the removal of $\mathrm{NO}_{\mathrm{x}}$ by ING, while ${ }_{\mathrm{S}}^{\mathrm{p}} \mathcal{S}_{\mathrm{E}(\mathrm{ISOP})}^{\mathrm{O}_{3}}$ can be positive during the biomass burning season, when boundary layer ozone over South America is less impacted by isoprene photochemistry. The importance of VOC transport thus depends on the boundary layer budget of ozone, which is largely controlled by $\mathcal{D}_{\text {ING. }}$. It follows that ING photochemistry may indirectly modulate the large-scale effect of isoprene photooxidation on the $\mathrm{O}_{\mathrm{x}}$ budget.
The large-scale influence of isoprene emissions can be contrasted to that of lightning and biomass burning $\mathrm{NO}_{\mathrm{x}}$. The large-scale effect of lightning is significantly greater than that of isoprene emissions and may not proceed through the same mechanisms as ${ }_{\mathrm{A}}^{\mathrm{p} / \mathrm{S}} \mathcal{S}_{\mathrm{E}_{\mathrm{li}}\left(\mathrm{NO}_{\mathrm{x}}\right)}^{\mathrm{NO}_{\mathrm{x}}}>0$ suggests a direct impact on the local ozone production far from its source regions. In contrast, the intercontinental effect of biomass burning is much more limited than that of isoprene and is not associated with large-scale transport of $\mathrm{NO}_{\mathrm{x}}$. Injection of biomass burning emissions outside of the boundary layer (Val Martin et al., 2010) as well as the formation of PAN in biomass burning plumes (Hudman et al., 2007; Yokelson et al., 2009; Alvarado et al., 2010) may, however, extend the spatial impact of biomass burning on tropical ozone (Poisson et al., 2000; Roelofs and Lelieveld, 2000).

\subsection{Isoprene nitrates as $\mathrm{NO}_{\mathrm{x}}$ reservoirs $\left(D_{\mathrm{ING}}<0\right)$}

In this section, we focus on near shore oceanic basins, downwind of major isoprene emissions. In these regions, ING photooxidation contributes significantly to the $\mathrm{NO}_{\mathrm{x}}$ source (Fig. 3). The impact of isoprene photochemistry on $\mathrm{O}_{\mathrm{x}}$ budget reflects the competition between the transport of continental ozone over continental regions (greater continental $\mathcal{D}_{\text {ING }}$ ) and greater ozone production downwind. Despite the loss of $\mathrm{NO}_{\mathrm{x}}$ during its export (through deposition), this competition can result in an increase in $\mathrm{O}_{\mathrm{x}}$ downwind of ING production regions, since the OPE is generally greater far from $\mathrm{NO}_{\mathrm{x}}$ sources.

It follows that $\mathrm{ING}_{0}$ and $\mathrm{ING}_{1}$ are too short-lived to contribute significantly to the transport of $\mathrm{NO}_{\mathrm{x}}$ since $\mathrm{S} \mathcal{S}_{\mathrm{OH}_{3}+\mathrm{ING}_{0}}^{\mathrm{O}_{3}}{ }^{\mathrm{S}} \mathcal{S}_{\mathrm{O}_{3}+\mathrm{ING}_{0}}$ and ${ }^{\mathrm{O}} \mathcal{S}_{\mathrm{OH}+\mathrm{ING}_{1}}^{\mathrm{O}_{3}}$ are positive, even over oceanic basins: their impact primarily reflects their modulation of ozone production and transport from continental regions. ${ }^{\mathrm{S}} \mathcal{S}_{\mathrm{OH}+\mathrm{ING}_{0}}^{\mathrm{O}_{3}}$ is negative reflecting the competition with the $\mathrm{O}_{3}$ channel that has a greater $\mathrm{NO}_{\mathrm{x}}$ recycling efficiency. Unlike $\mathrm{ING}_{0}$ and $\mathrm{ING}_{1},{ }^{\mathrm{S}} \mathcal{S}_{\mathrm{OH}+\mathrm{ING} 2}$ is generally negative: $\mathrm{ING}_{2}$ contribution to $\mathrm{NO}_{\mathrm{x}}$ transport to high $\mathrm{OPE}$ 


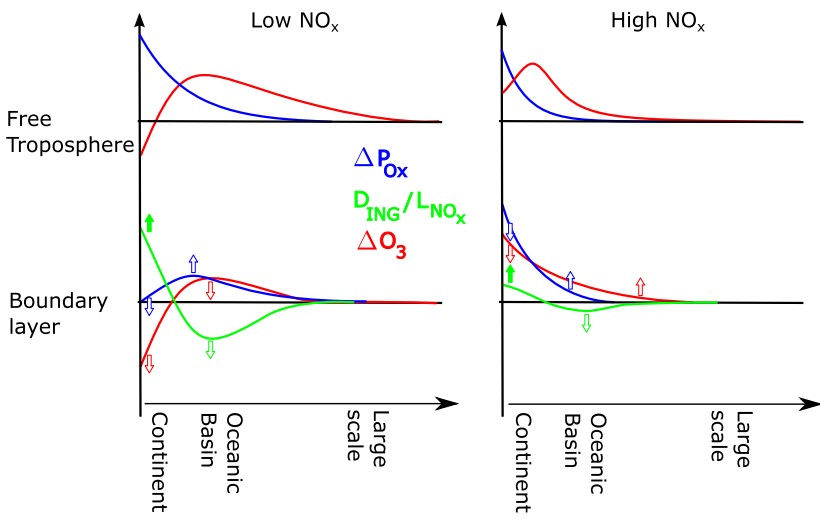

Fig. 9. Schematic representation of the spatial modulation of the $\mathrm{O}_{\mathrm{x}}$ budget by the isoprene photochemical cascade. Isoprene chemistry alters ozone production (blue) locally by altering the abundance of $\mathrm{NO}_{\mathrm{x}}$; reduction in $\mathrm{NO}_{\mathrm{x}}$ due to formation of isoprene nitrates $\left(\mathcal{D}_{\mathrm{ING}} / \mathcal{L}_{\mathrm{NO}_{\mathrm{x}}}\right.$, continent) leads to reductions in $\mathrm{O}_{\mathrm{x}}$. Downwind of continents, however, the release of $\mathrm{NO}_{\mathrm{x}}$ by ING promotes ozone formation. The resulting net impact of isoprene photochemistry on regional ozone, thus, depends on the $\mathrm{NO}_{\mathrm{x}}$ conditions near isoprene source regions. Under high- $\mathrm{NO}_{\mathrm{x}}$, an increase in the continental removal of $\mathrm{NO}_{\mathrm{x}}$ (green filled arrow, right panel) by isoprene results in a net increase of ozone downwind of continents $\left(\Delta \mathrm{O}_{3}>0\right.$, red empty arrows). This reflects the enhanced transport of nitrogen reservoirs from regions of low OPE (continents) to regions of high OPE (oceans). Conversely, under low- $\mathrm{NO}_{\mathrm{x}}$, a similar increase in $\mathrm{NO}_{\mathrm{x}}$ removal (green filled arrow, left panel) can result in a decrease of ozone downwind of continents, as the contrast in OPE is not sufficient to overcome the decrease in continental ozone advected as well as the increased loss of $\mathrm{NO}_{\mathrm{x}}$ during its transport (e.g., deposition of ING). The removal of $\mathrm{NO}_{\mathrm{x}}$ by isoprene nitrate chemistry also increases the amount of BVOCs injected in the free troposphere, promoting the production of ozone. This indirect effect of isoprene chemistry on ozone is of opposite sign to the direct effect and impacts ozone away from isoprene sources.

regions outweighs the associated increase in the removal of $\mathrm{NO}_{\mathrm{x}}$ (Fig. S8).

An example of this competition between transport of $\mathrm{NO}_{\mathrm{x}}$ and transport of ozone is the sensitivity of South Atlantic ozone to the recycling of $\mathrm{NO}_{\mathrm{x}}$ from $\mathrm{ING}_{0}$ phootooxidation $(\alpha) .{ }^{a} \mathcal{S}_{\alpha} \mathrm{O}_{3}$ vary seasonally and spatially in response to changing photochemical conditions over Africa (Fig. 8). ${ }_{\mathrm{A}}^{\text {a }} \mathcal{S}_{\alpha} \mathrm{O}_{3}$ is positive where isoprene peroxy radicals react primarily with $\mathrm{HO}_{2}$ (e.g., from April to May). Under these conditions, the increase in OPE between the isoprene emission region and the receptor region is not large enough to compensate for the loss of $\mathrm{NO}_{\mathrm{x}}$ during its export. Conversely, ${ }_{\mathrm{A}}^{\mathrm{S}} \mathcal{S}_{\alpha}^{\mathrm{O}_{3}}$ is negative where isoprene peroxy radicals primarily react with NO, i.e. where $\mathcal{D}_{\text {ING }}$ is low and the impact of ING chemistry on the local $\mathcal{P}_{\mathrm{O}_{\mathrm{x}}}$ is limited (e.g., from December to February, where biomass burning and isoprene emissions are collocated). Under these conditions, the contrast in OPE can be very large and the increase in the transport of $\mathrm{NO}_{\mathrm{x}}$ outweighs the decrease in the local production of ozone. From ${ }_{\mathrm{A}}^{\mathrm{t}} \mathcal{S}_{\alpha} \mathrm{O}_{3}<0$ and ${ }_{\mathrm{A}}^{\mathrm{A}} \mathcal{S}_{\alpha} \mathrm{O}_{3}>0$ (consistent with $\partial \mathcal{D}_{\mathrm{ING}} / \partial \alpha<0$ ) in the December to February period, it follows that the large-scale impact dominates over the regional-scale one under elevated $\mathrm{NO}_{\mathrm{x}}$ conditions.

\subsection{Can the effect of chemistry, emissions and dynamics on the tropical $O_{x}$ budget be separated using experimental observations?}

In the previous sections, we have shown that the oxidation of biogenics modulates the budget of $\mathrm{O}_{\mathrm{x}}$ and that this modulation can vary dramatically in space and time as summarized in Fig. 9. Thus, the difference in the representation of this coupling across models need to be accounted for when analyzing intermodel differences of tropical $\mathrm{O}_{\mathrm{x}}$ (Stevenson et al., 2006). More generally, uncertainties in the model chemical transfer functions should be better characterized.

Most studies focusing on tropical ozone have been devoted to improving the estimates of $\mathrm{NO}_{\mathrm{x}}$ emissions from lightning, biomass burning and soil to achieve better agreement with ozone measurements (Sauvage et al., 2007b; Jaeglé et al., 2004; Ziemke et al., 2009). It follows from this study, however, that the impact of changes in $\mathrm{NO}_{\mathrm{x}}$ emissions on the $\mathrm{O}_{\mathrm{x}}$ budget cannot be readily separated from their modulation by different representations of the photooxidation of biogenics and transport processes (in particular deep convection (Nassar et al., 2009)). Thus, the uncertainty of $\mathrm{NO}_{\mathrm{x}}$ emissions derived from ozone or $\mathrm{NO}_{2}$ measurements will be commensurate with errors in the representation of these processes.

The different factors investigated here exhibit different seasonal and geographical behavior that can be used to unravel their coupling. Several avenues for further study can be inferred from this work:

- the ozone contrast between land and ocean is predicted to be amplified by biomass burning but reduced by lightning and the transport of $\mathrm{NO}_{\mathrm{x}}$ reservoirs. The differences in seasonal and interannual variability of biomass burning and biogenic emissions combined with the availability of long record of tropospheric ozone (e.g., OMI) may help disentangle the different contributors to tropical ozone (Martin et al., 2000). In particular, we find that ${ }_{\mathrm{A}}^{\mathrm{a}} \mathcal{S}_{\mathrm{E} \text { (ISOP) }}^{\mathrm{O}_{3}}$ and ${ }_{\mathrm{A}}^{\mathrm{a}} \mathcal{S}_{\mathrm{E}_{\mathrm{bb}}\left(\mathrm{NO}_{\mathrm{x}}\right)}$ are of similar magnitudes (Fig. S10). This is at odds with the conclusions of Sauvage et al. (2007b) who found that the dependence of Atlantic ozone on isoprene emissions is negligible. This may be associated with the treatment of isoprene nitrates as a terminal sink of $\mathrm{NO}_{\mathrm{x}}$ in the standard GEOS-Chem mechanism.

- the fraction of isoprene (and more generally biogenic volatile organic compound) oxidized in the upper troposphere (i.e., vertical profile of isoprene or formaldehyde) governs the large-scale impact of short-lived 
volatile organic compound on the $\mathrm{O}_{\mathrm{x}}$ budget. Instruments such as TES, IASI and ACE-FTS provide some information on the vertical profile of many chemical compounds that are impacted differently by $\mathrm{NO}_{\mathrm{x}}$ and biogenic emissions. These multi-compounds analysis has been used to investigate the budget of ozone (Bowman et al., 2009; Cooper et al., 2011) or formic acid (Gonzàlez Abad et al., 2009; Paulot et al., 2011). Vertical profiles also provide essential constraints on the photooxidative conditions in the boundary layer, complementing surface measurements. In particular, if the fraction of isoprene oxidized outside of the boundary layer is found to be overestimated by the model, this would confirm that $\mathrm{HO}_{\mathrm{x}}$ concentration in high isoprene/low $\mathrm{NO}_{\mathrm{x}}$ environments are higher than simulated (Stone et al., 2010). Such a multi-compound approach may also be useful to constrain isoprene emissions from satellite observations of formaldehyde total column (Palmer et al., 2003). Under low- $\mathrm{NO}_{\mathrm{x}}$ conditions, i.e., where the fate of $\mathrm{ISOPO}_{2}$ is dominated by reactions with $\mathrm{HO}_{2}$ and isomerization, it is unlikely that isoprene emissions can be directly related to formaldehyde total columns (Barkley et al., 2008). Instead, a formal inversion approach explicitly taking into account the spatial and vertical footprint of isoprene emissions on formaldehyde is probably required (Fig. S11). Better experimental constraints on the yield of $\mathrm{CH}_{2} \mathrm{O}$ from ISOPOOH and IEPOX are also critical.

- The sensitivity of ozone to isoprene photochemistry can be altered by changes in anthropogenic activities. This is illustrated by the sensitivity of ozone to anthropogenic $\mathrm{NO}_{\mathrm{x}}$ emissions in Java. Ozone is also very sensitive to soil $\mathrm{NO}_{\mathrm{x}}$ emissions (Fig. 6), which are also affected by human activities such as deforestation (Keller et al., 1991, 2005). To explore further the sensitivity of the interplay between ozone and biogenics activities, we modify anthropogenic emissions of $\mathrm{NO}_{\mathrm{x}}$ such that $\mathrm{NO}_{\mathrm{x}}$ emissions per capita are identical to those of North America (7.8 kg(NO)/yr/person, circa 2005) everywhere. This extreme scenario yields a large increase in $\mathrm{OH}(\sim 30 \%)$ and tropical ozone (Fig. S12). ${ }^{\mathrm{t}} \mathcal{S}_{\mathrm{E}(\mathrm{ISOP})}^{\mathrm{O}_{3}}$ increases throughout the tropics (Fig. 10). This increase can be large enough to make ${ }^{t} \mathcal{S}_{\mathrm{E}}^{\mathrm{O}_{3}}$ (ISOP) positive in regions where it is negative in the present-day simulation. Since some tropical crops are known to emit more isoprene than the rain forest they replace, this would further amplify the ozone increase associated with direct anthropogenic emissions (Hewitt et al., 2009). Similarly, negative ${ }^{t} \mathcal{S}_{\alpha}^{\mathrm{O}_{3}}$ are not isolated to Africa as in the reference simulation but extend to large regions of the tropics (Fig. S13), underlying the profound change in the chemical regime of the tropics if all inhabitants had the same $\mathrm{NO}_{\mathrm{x}}$ emissions per capita as North Americans.
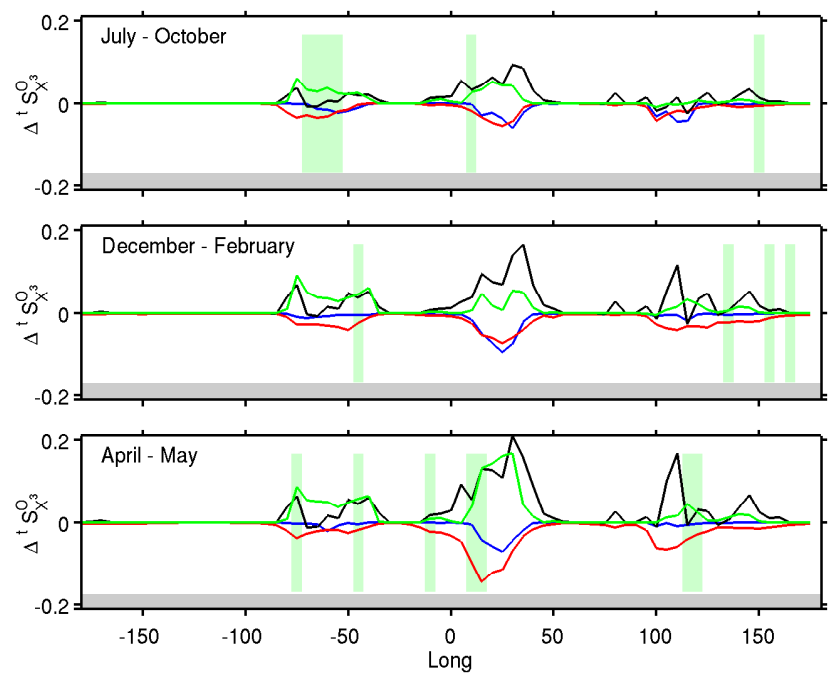

Fig. 10. Absolute changes in the adjoint sensitivity of tropospheric tropical ozone resulting from a large increase in anthropogenic emissions of $\mathrm{NO}_{\mathrm{X}}$ (cf. Sect. 4.4 $\Delta^{\mathrm{t}} \mathcal{S}_{\mathrm{X}}^{\mathrm{O}_{3}}={ }^{\mathrm{t}} \mathcal{S}_{\mathrm{X}}^{\mathrm{O}_{3}}$ (high tropical $\mathrm{NO}_{\mathrm{X}}$ emissions) $-{ }^{\mathrm{t}} \mathcal{S}_{\mathrm{X}}^{\mathrm{O}_{3}}$ (reference), with ${ }^{\mathrm{t}} \mathcal{S}_{\mathrm{X}}^{\mathrm{O}_{3}}$ in $\% / 0$ ) to changes in the emissions of isoprene (green), lightning $\mathrm{NO}_{\mathrm{X}}$ (red), biomass burning $\mathrm{NO}_{\mathrm{x}}$ (blue) and anthropogenic $\mathrm{NO}_{\mathrm{x}}$ (black) resulting from a very large increase in anthropogenic $\mathrm{NO}_{\mathrm{x}}$ emissions. Green-shaded areas denote regions where ${ }^{t} \mathcal{S}_{\mathrm{X}}^{\mathrm{O}_{3}}$ become positive because of higher $\mathrm{NO}_{\mathrm{x}}$ emissions. The grey shaded region denotes the regions over which the cost function are evaluated.

\section{Conclusions}

The rapid economic development of the tropical regions calls for a better assessment of how anthropogenic perturbations may influence the concentration of ozone and assess the consequences of this change on food security (Van Dingenen et al., 2009; Hewitt et al., 2009), human health (World Health Organization, 2005) and radiative forcing (directly or indirectly (e.g., Sitch et al., 2007).

In this work, we have shown that accurate simulation of tropical ozone must take into account the modulation of the $\mathrm{O}_{\mathrm{x}}$ budget by the photooxidation of biogenics. In particular, the regional simulation of ozone is shown to be very sensitive to the removal and export of $\mathrm{NO}_{\mathrm{x}}$ by isoprene nitrates. In South America and New Guinea, the high ratio of isopreneto- $\mathrm{NO}_{\mathrm{x}}$ emissions makes isoprene nitrates chemistry the primary sink of $\mathrm{NO}_{\mathrm{x}}$.

We have also shown that the impact of isoprene photooxidation on tropical ozone is not limited to the regional scale. We hypothesize that this long-range effect is the result of dynamic and photochemical processes: efficient vertical mixing (through deep convection) and low boundary layer $\mathrm{HO}_{\mathrm{x}}$ (as a result of high biogenics and low $\mathrm{NO}_{\mathrm{x}}$ emissions). These conditions, promote the oxidation of isoprene outside of the boundary layer, where its contribution to ozone production is amplified. The inability of models to reproduce ground 
$\mathrm{HO}_{\mathrm{x}}$ observations may thus have consequences beyond the regional scale.

From this work, it is clear that the effect of the photochemistry of biogenics on ozone cannot be simply isolated from that of emissions, even on the global scale. In particular, a better understanding of the coupling of isoprene with $\mathrm{NO}_{\mathrm{x}}$ emissions requires a much improved representation of the isoprene photochemical cascade as a whole, since many of the large scale effects presented here result from the photochemistry of second-, third-, etc.-generation photochemical products.

\section{Appendix A}

\section{Notations}

\begin{tabular}{|c|c|}
\hline $\begin{array}{l}\mathrm{R}_{\mathrm{y}} \\
{ }_{\mathrm{R}} \mathcal{S}_{\mathrm{X}}^{\mathrm{Y}}\end{array}$ & $\begin{array}{l}\text { normalized sensitivity of mean tropospheric } \\
\text { Y over the region } R_{y} \text { to changes in } X \\
\text { over the region } R_{x} . \text { For photochemical } \\
\text { processes, unless otherwise noted, } \\
R_{y} \text { extends from the surface to the } \\
\text { tropopause. }{ }_{R_{y}} \mathcal{S}_{X}^{Y} \text { is expressed in } \% \text { per } \\
\text { degree longitude. }\end{array}$ \\
\hline $\mathrm{a}$ & Atlantic $\left(R_{x}, R_{y}\right)$ \\
\hline A & Africa $\left(R_{x}, R_{y}\right)$ \\
\hline $\mathrm{p}$ & Pacific $\left(R_{x}, R_{y}\right)$ \\
\hline $\mathrm{S}$ & South America $\left(R_{x}, R_{y}\right)$ \\
\hline $\mathrm{s}$ & Southeast Asia $\left(R_{x}, R_{y}\right)$ \\
\hline $\mathrm{t}$ & Tropics $\left(R_{x}, R_{y}\right)$ \\
\hline $\mathrm{w}$ & World $\left(R_{x}, R_{y}\right)$ \\
\hline $\mathcal{D}_{\mathrm{ING}}$ & $\begin{array}{l}\text { net effect of ING chemistry on the } \mathrm{NO}_{\mathrm{x}} \\
\text { budget }\end{array}$ \\
\hline $\mathcal{L}_{\mathrm{NO}_{\mathrm{x}}}$ & $\begin{array}{l}\text { Loss of } \mathrm{NO}_{\mathrm{x}} \text { (account for the role of PAN and } \\
\text { ING as } \mathrm{NO}_{\mathrm{x}} \text { reservoirs) }\end{array}$ \\
\hline $\mathcal{P}_{\mathrm{X}}$ & Photochemical production of $\mathrm{X}$ \\
\hline $\mathrm{E}_{\mathrm{bb}}\left(\mathrm{NO}_{\mathrm{x}}\right)$ & $\mathrm{NO}_{\mathrm{x}}$ emissions from biomass burning \\
\hline $\mathrm{E}_{\mathrm{li}}\left(\mathrm{NO}_{\mathrm{x}}\right)$ & $\mathrm{NO}_{\mathrm{x}}$ emissions from lightning \\
\hline E(ISOP) & Isoprene emissions \\
\hline Y & Isoprene nitrate yield \\
\hline$\alpha$ & $\mathrm{NO}_{\mathrm{x}}$ recycling from $\mathrm{ING}_{0}$ photooxidation \\
\hline
\end{tabular}

\section{Supplement related to this article is available online at: http://www.atmos-chem-phys.net/12/1307/2012/ acp-12-1307-2012-supplement.pdf.}

Acknowledgements. This manuscript greatly benefited from the comments of two anonymous reviewers. The authors also thank M. R. Beaver, J. D. Crounse and Y. Xie for helpful discussions. F. P. was supported by a NASA Earth and Space Science Fellowship. DKH was supported by the NASA New Investigator Program. Simulations were performed on Caltech's Division of Geological and Planetary Sciences Dell cluster.
Edited by: R. Cohen

\section{References}

Aghedo, A. M., Schultz, M. G., and Rast, S.: The influence of African air pollution on regional and global tropospheric ozone, Atmos. Chem. Phys., 7, 1193-1212, doi:10.5194/acp-7-11932007, 2007.

Alvarado, M. J., Logan, J. A., Mao, J., Apel, E., Riemer, D., Blake, D., Cohen, R. C., Min, K.-E., Perring, A. E., Browne, E. C., Wooldridge, P. J., Diskin, G. S., Sachse, G. W., Fuelberg, H., Sessions, W. R., Harrigan, D. L., Huey, G., Liao, J., CaseHanks, A., Jimenez, J. L., Cubison, M. J., Vay, S. A., Weinheimer, A. J., Knapp, D. J., Montzka, D. D., Flocke, F. M., Pollack, I. B., Wennberg, P. O., Kurten, A., Crounse, J., Clair, J. M. S., Wisthaler, A., Mikoviny, T., Yantosca, R. M., Carouge, C. C., and Le Sager, P.: Nitrogen oxides and PAN in plumes from boreal fires during ARCTAS-B and their impact on ozone: an integrated analysis of aircraft and satellite observations, Atmos. Chem. Phys., 10, 9739-9760, doi:10.5194/acp-10-97392010, 2010.

Archibald, A. T., Cooke, M. C., Utembe, S. R., Shallcross, D. E., Derwent, R. G., and Jenkin, M. E.: Impacts of mechanistic changes on $\mathrm{HO}_{x}$ formation and recycling in the oxidation of isoprene, Atmos. Chem. Phys., 10, 8097-8118, doi:10.5194/acp10-8097-2010, 2010.

Barkley, M. P., Palmer, P. I., Kuhn, U., Kesselmeier, J., Chance, K., Kurosu, T. P., Martin, R. V., Helmig, D., and Guenther, A.: Net ecosystem fluxes of isoprene over tropical South America inferred from Global Ozone Monitoring Experiment (GOME) observations of HCHO columns, J. Geophys. Res., 113, doi:10.1029/2008JD009863, 2008.

Bechara, J., Borbon, A., Jambert, C., Colomb, A., and Perros, P. E.: Evidence of the impact of deep convection on reactive Volatile Organic Compounds in the upper tropical troposphere during the AMMA experiment in West Africa, Atmos. Chem. Phys., 10, 10321-10334, doi:10.5194/acp-10-10321-2010, 2010.

Bey, I., Jacob, D. J., Yantosca, R. M., Logan, J. A., Field, B. D., Fiore, A. M., Li, Q., Liu, H. Y., Mickley, L. J., and Schultz, M. G.: Global modeling of tropospheric chemistry with assimilated meteorology - Model description and evaluation, J. Geophys. Res., 106, 23073-23095, doi:10.1029/2001JD000807, 2001.

Bowman, K. W., Jones, D. B. A., Logan, J. A., Worden, H., Boersma, F., Chang, R., Kulawik, S., Osterman, G., Hamer, P., and Worden, J.: The zonal structure of tropical $\mathrm{O}_{3}$ and $\mathrm{CO}$ as observed by the Tropospheric Emission Spectrometer in November 2004 - Part 2: Impact of surface emissions on $\mathrm{O}_{3}$ and its precursors, Atmos. Chem. Phys., 9, 3563-3582, doi:10.5194/acp-93563-2009, 2009.

Boyd, A. A., Flaud, P.-M., Daugey, N., and Lesclaux, R.: Rate Constants for $\mathrm{RO}_{2}+\mathrm{HO}_{2}$ Reactions Measured under a Large Excess of $\mathrm{HO}_{2}$, J. Phys. Chem. A, 107, 818-821, doi:10.1021/jp026581r, 2003.

Brown, S. S., deGouw, J. A., Warneke, C., Ryerson, T. B., Dubé, W. P., Atlas, E., Weber, R. J., Peltier, R. E., Neuman, J. A., Roberts, J. M., Swanson, A., Flocke, F., McKeen, S. A., Brioude, J., Sommariva, R., Trainer, M., Fehsenfeld, F. C., and Ravishankara, A. R.: Nocturnal isoprene oxidation over the Northeast 
United States in summer and its impact on reactive nitrogen partitioning and secondary organic aerosol, Atmos. Chem. Phys., 9, 3027-3042, doi:10.5194/acp-9-3027-2009, 2009.

Chameides, W. L., Lindsay, R. W., Richardson, J., and Kiang, C. S.: The role of biogenic hydrocarbons in urban photochemical smog: Atlanta as a case study, Science, 241, 1473, doi:10.1126/science.3420404, 1988.

Chandra, S., Ziemke, J. R., Bhartia, P. K., and Martin, R. V.: Tropical tropospheric ozone: Implications for dynamics and biomass burning, J. Geophys. Res. Atmos., 107, 4188,doi:10.1029/2001JD000447, 2002.

Chen, X., Hulbert, D., and Shepson, P. B.: Measurement of the organic nitrate yield from $\mathrm{OH}$ reaction with isoprene, J. Geophys. Res., 103, 25563-25568, doi:10.1029/98JD01483, 1998.

Collins, W. J., Stevenson, D. S., Johnson, C. E., and Derwent, R. G.: Role of convection in determining the budget of odd hydrogen in the upper troposphere, J. Geophys. Res., 104, 26927-26942, doi:10.1029/1999JD900143, 1999.

Colomb, A., Williams, J., Crowley, J., Gros, V., Hofmann, R., Salisbury, G., Klüpfel, T., Kormann, R., Stickler, A., Forster, C., et al.: Airborne measurements of trace organic species in the upper troposphere over Europe: the impact of deep convection, Environ. Chem., 3, 244-259, doi:10.1071/EN06020, 2006.

Cooper, M., Martin, R., Sauvage, B., Boone, C., Walker, K., Bernath, P., McLinden, C., Degenstein, D., Volz-Thomas, A., and Wespes, C.: Evaluation of ACE-FTS and OSIRIS Satellite retrievals of ozone and nitric acid in the tropical upper troposphere: Application to ozone production efficiency, J. Geophys. Res., 116, D12306,doi:10.1029/2010JD015056, 2011.

Crounse, J. D., Paulot, F., Kjaergaard, H. G., and Wennberg, P. O.: Peroxy radical isomerization in the oxidation of isoprene, Phys. Chem. Chem. Phys., 13, 13607-13613,doi:10.1039/c1cp21330j, 2011.

Dibble, T. S.: Intramolecular hydrogen bonding and double H-atom transfer in peroxy and alkoxy radicals from isoprene, J. Phys. Chem. A, 108, 2199-2207, doi:10.1021/jp0306702, 2004a.

Dibble, T. S.: Prompt chemistry of alkenoxy radical products of the double $\mathrm{H}$-atom transfer of alkoxy radicals from isoprene, J. Phys. Chem. A, 108, 2208-2215,doi:10.1021/jp0312161, 2004b.

Doherty, R. M., Stevenson, D. S., Collins, W. J., and Sanderson, M. G.: Influence of convective transport on tropospheric ozone and its precursors in a chemistry-climate model, Atmos. Chem. Phys., 5, 3205-3218, doi:10.5194/acp-5-3205-2005, 2005.

Edwards, D. P., Emmons, L. K., Gille, J. C., Chu, A., Attié, J., Giglio, L., Wood, S. W., Haywood, J., Deeter, M. N., Massie, S. T., Ziskin, D. C., and Drummond, J. R.: Satellite-observed pollution from Southern Hemisphere biomass burning, J. Geophys. Res. Atmos., 111, D14312, doi:10.1029/2005JD006655, 2006.

Fiore, A. M., Jacob, D. J., Mathur, R., and Martin, R. V.: Application of empirical orthogonal functions to evaluate ozone simulations with regional and global models, J. Geophys. Res., 108, 4431, doi:10.1029/2002JD003151, 2003.

Fiore, A. M., Horowitz, L. W., Purves, D. W., II, H. L., Evans, M. J., Wang, Y., Li, Q., and Yantosca, R. M.: Evaluating the contribution of changes in isoprene emissions to surface ozone trends over the eastern United States, J. Geophys. Res, 110, D12303, doi:10.1029/2004JD005485, 2005.

Forster, P., Ramaswamy, V., Artaxo, P., Berntsen, T., Betts, R., Fa- hey, D. W., Haywood, J., Lean, J., Lowe, D. C., Myhre, G., Nganga, J., Prinn, R., Raga, G., Schulz, M., and Van Dorland, R.: Changes in atmospheric constituents and in radiative forcing, Climate Change 2007: The Physical Science Basis. Contribution of Working Group I to the Fourth Assessment Report of the Intergovernmental Panel on Climate Change, Cambridge University Press, 2007.

Froyd, K. D., Murphy, S. M., Murphy, D. M., de Gouw, J. A., Eddingsaas, N. C., and Wennberg, P. O.: Contribution of isoprene-derived organosulfates to free tropospheric aerosol mass, Proc. Natl. Acad. Sci., 107, 21 360-21365, doi:10.1073/pnas.1012561107, 2010.

Gauss, M., Myhre, G., Isaksen, I. S. A., Grewe, V., Pitari, G., Wild, O., Collins, W. J., Dentener, F. J., Ellingsen, K., Gohar, L. K., Hauglustaine, D. A., Iachetti, D., Lamarque, F., Mancini, E., Mickley, L. J., Prather, M. J., Pyle, J. A., Sanderson, M. G., Shine, K. P., Stevenson, D. S., Sudo, K., Szopa, S., and Zeng, G.: Radiative forcing since preindustrial times due to ozone change in the troposphere and the lower stratosphere, Atmos. Chem. Phys., 6, 575-599, doi:10.5194/acp-6-575-2006, 2006.

Giacopelli, P., Ford, K., Espada, C., and Shepson, P. B.: Comparison of the measured and simulated isoprene nitrate distributions above a forest canopy, J. Geophys. Res., 110, D01304, doi:10.1029/2004JD005123, 2005.

Giering, R. and Kaminski, T.: Recipes for adjoint code construction, ACM Transactions on Mathematical Software (TOMS), 24, 437-474, 1998.

Gonzàlez Abad, G., Bernath, P. F., Boone, C. D., McLeod, S. D., Manney, G. L., and Toon, G. C.: Global distribution of upper tropospheric formic acid from the ACE-FTS, Atmos. Chem. Phys., 9, 8039-8047, doi:10.5194/acp-9-8039-2009, 2009.

Grossenbacher, J. W., Couch, T., Shepson, P. B., Thornberry, T., Witmer-Rich, M., Carroll, M. A., Faloona, I., Tan, D., Brune, W., Ostling, K., and Bertman, S.: Measurements of isoprene nitrates above a forest canopy, J. Geophys. Res., 106, 2442924438, doi:10.1029/2001JD900029, 2001.

Grossenbacher, J. W., Barket, Jr., D. J., Shepson, P. B., Carroll, M. A., Olszyna, K., and Apel, E.: A comparison of isoprene nitrate concentrations at two forest-impacted sites, J. Geophys. Res. Atmos., 109, D11311, doi:10.1029/2003JD003966, 2004.

Guenther, A., Hewitt, C. N., Erickson, D., Fall, R., Geron, C., Graedel, T., Harley, P., Klinger, L., Lerdau, M., McKay, W. A., Pierce, T., Scholes, B., Steinbrecher, R., Tallamraju, R., Taylor, J., and Zimmerman, P.: A global model of natural volatile organic compound emissions, J. Geophys. Res., 100, 8873-8892, doi:10.1029/94JD02950, 1995.

Guenther, A., Karl, T., Harley, P., Wiedinmyer, C., Palmer, P. I., and Geron, C.: Estimates of global terrestrial isoprene emissions using MEGAN (Model of Emissions of Gases and Aerosols from Nature), Atmos. Chem. Phys., 6, 3181-3210, doi:10.5194/acp-63181-2006, 2006.

Henze, D. K., Hakami, A., and Seinfeld, J. H.: Development of the adjoint of GEOS-Chem, Atmos. Chem. Phys., 7, 2413-2433, doi:10.5194/acp-7-2413-2007, 2007.

Henze, D. K., Seinfeld, J. H., and Shindell, D. T.: Inverse modeling and mapping US air quality influences of inorganic $\mathrm{PM}_{2.5}$ precursor emissions using the adjoint of GEOS-Chem, Atmos. Chem. Phys., 9, 5877-5903, doi:10.5194/acp-9-5877-2009, 2009. 
Hewitt, C. N., MacKenzie, A. R., Di Carlo, P., Di Marco, C. F., Dorsey, J. R., Evans, M., Fowler, D., Gallagher, M. W., Hopkins, J. R., Jones, C. E., Langford, B., Lee, J. D., Lewis, A. C., Lim, S. F., McQuaid, J., Misztal, P., Moller, S. J., Monks, P. S., Nemitz, E., Oram, D. E., Owen, S. M., Phillips, G. J., Pugh, T. A. M., Pyle, J. A., Reeves, C. E., Ryder, J., Siong, J., Skiba, U., and Stewart, D. J.: Nitrogen management is essential to prevent tropical oil palm plantations from causing groundlevel ozone pollution, Proc. Natl. Acad. Sci., 106, 18447-18451, doi:10.1073/pnas.0907541106, 2009.

Horowitz, L. W., Liang, J., Gardner, G. M., and Jacob, D. J.: Export of reactive nitrogen from North America during summertime - Sensitivity to hydrocarbon chemistry, J. Geophys. Res., 103, 13451-13476, 1998.

Horowitz, L. W., Fiore, A. M., Milly, G. P., Cohen, R. C., Perring, A., Wooldridge, P. J., Hess, P. G., Emmons, L. K., and Lamarque, J.: Observational constraints on the chemistry of isoprene nitrates over the eastern United States, J. Geophys. Res., 112, D12S08 doi:10.1029/2006JD007747, 2007.

Houweling, S., Dentener, F., and Lelieveld, J.: The impact of nonmethane hydrocarbon compounds on tropospheric photochemistry, J. Geophys. Res., 103, 10673-10696, doi:10.1029/97JD03582, 1998.

Hudman, R. C., Jacob, D. J., Turquety, S., Leibensperger, E. M., Murray, L. T., Wu, S., Gilliland, A. B., Avery, M., Bertram, T. H., Brune, W., Cohen, R. C., Dibb, J. E., Flocke, F. M., Fried, A., Holloway, J., Neuman, J. A., Orville, R., Perring, A., Ren, X., Sachse, G. W., Singh, H. B., Swanson, A., and Wooldridge, P. J.: Surface and lightning sources of nitrogen oxides over the United States: Magnitudes, chemical evolution, and outflow, J. Geophys. Res., 112, D12S05, doi:10.1029/2006JD007912, 2007.

Ito, A., Sillman, S., and Penner, J. E.: Effects of additional nonmethane volatile organic compounds, organic nitrates, and direct emissions of oxygenated organic species on global tropospheric chemistry, J. Geophys. Res., 112, D06309, doi:10.1029/2005JD006556, 2007.

Ito, A., Sillman, S., and Penner, J. E.: Global chemical transport model study of ozone response to changes in chemical kinetics and biogenic volatile organic compounds emissions due to increasing temperatures: Sensitivities to isoprene nitrate chemistry and grid resolution, J. Geophys. Res. Atmos., 114, D09301,doi:10.1029/2008JD011254, 2009.

Jacob, D. J. and Winner, D. A.: Effect of climate change on air quality, Atmos. Environ., 43, 51-63, doi:10.1016/j.atmosenv.2008.09.051, 2009.

Jacob, D. J., Heikes, B. G., Fan, S.-M., Logan, J. A., Mauzerall, D. L., Bradshaw, J. D., Singh, H. B., Gregory, G. L., Talbot, R. W., Blake, D. R., and Sachse, G. W.: Origin of ozone and $\mathrm{NO}_{\mathrm{x}}$ in the tropical troposphere: A photochemical analysis of aircraft observations over the South Atlantic basin, J. Geophys. Res., 101, 24235-24250, doi:10.1029/96JD00336, 1996.

Jacob, D. J., Liu, H., Mari, C., and Yantosca, R. M.: Harvard wet deposition scheme for GMI, 2000.

Jaeglé, L., Jacob, D. J., Brune, W. H., and Wennberg, P. O.: Chemistry of $\mathrm{HO}_{\mathrm{x}}$ radicals in the upper troposphere, Atmos. Environ., 35, 469-489, doi:10.1016/S1352-2310(00)00376-9, 2001.

Jaeglé, L., Martin, R. V., Chance, K., Steinberger, L., Kurosu, T. P., Jacob, D. J., Modi, A. I., Yoboue, V., Sigha-Nkamdjou, L., and Galy-Lacaux, C.: Satellite mapping of rain-induced ni- tric oxide emissions from soils, J. Geophys. Res., 109, D21310, doi:10.1029/2004JD004787, 2004.

Jenkin, M. E., Saunders, S. M., and Pilling, M. J.: The tropospheric degradation of volatile organic compounds: a protocol for mechanism development, Atmos. Environ., 31, 81-104, 1997.

Jourdain, L., Worden, H. M., Worden, J. R., Bowman, K., Li, Q., Eldering, A., Kulawik, S. S., Osterman, G., Boersma, K. F., Fisher, B., Rinsland, C. P., Beer, R., and Gunson, M.: Tropospheric vertical distribution of tropical Atlantic ozone observed by TES during the northern African biomass burning season, Geophys. Res. Lett., 34, L04810, doi:10.1029/2006GL028284, 2007.

Keller, M., Jacob, D., Wofsy, S., and Harriss, R.: Effects of tropical deforestation on global and regional atmospheric chemistry, Clim. Change, 19, 139-158, 1991.

Keller, M., Varner, R., Dias, J., Silva, H., Crill, P., de Oliveira Jr, R., and Asner, G.: Soil-atmosphere exchange of nitrous oxide, nitric oxide, methane, and carbon dioxide in logged and undisturbed forest in the Tapajos National Forest, Brazil, Earth Interact., 9, 1-28, doi:10.1175/EI125.1, 2005.

Kopacz, M., Jacob, D. J., Fisher, J. A., Logan, J. A., Zhang, L., Megretskaia, I. A., Yantosca, R. M., Singh, K., Henze, D. K., Burrows, J. P., Buchwitz, M., Khlystova, I., McMillan, W. W., Gille, J. C., Edwards, D. P., Eldering, A., Thouret, V., and Nedelec, P.: Global estimates of CO sources with high resolution by adjoint inversion of multiple satellite datasets (MOPITT, AIRS, SCIAMACHY, TES), Atmos. Chem. Phys., 10, 855-876, doi:10.5194/acp-10-855-2010, 2010.

Kopacz, M., Mauzerall, D. L., Wang, J., Leibensperger, E. M., Henze, D. K., and Singh, K.: Origin and radiative forcing of black carbon transported to the Himalayas and Tibetan Plateau, Atmos. Chem. Phys., 11, 2837-2852, doi:10.5194/acp-11-28372011, 2011.

Kuhn, U., Ganzeveld, L., Thielmann, A., Dindorf, T., Schebeske, G., Welling, M., Sciare, J., Roberts, G., Meixner, F. X., Kesselmeier, J., Lelieveld, J., Kolle, O., Ciccioli, P., Lloyd, J., Trentmann, J., Artaxo, P., and Andreae, M. O.: Impact of Manaus City on the Amazon Green Ocean atmosphere: ozone production, precursor sensitivity and aerosol load, Atmos. Chem. Phys., 10, 9251-9282,doi:10.5194/acp-10-9251-2010, 2010.

Lelieveld, J., Butler, T. M., Crowley, J. N., Dillon, T. J., Fischer, H., Ganzeveld, L., Harder, H., Lawrence, M. G., Martinez, M., Taraborrelli, D., et al.: Atmospheric oxidation capacity sustained by a tropical forest, Nature, 452, 737,doi:10.1038/nature06870, 2008.

Liu, S. C., Trainer, M., Fehsenfeld, F. C., Parrish, D. D., Williams, E. J., Fahey, D. W., Hübler, G., and Murphy, P. C.: Ozone production in the rural troposphere and the implications for regional and global ozone distributions, J. Geophys. Res., 92, 4191-4207, doi:10.1029/JD092iD04p04191, 1987.

Lockwood, A. L., Shepson, P. B., Fiddler, M. N., and Alaghmand, M.: Isoprene nitrates: preparation, separation, identification, yields, and atmospheric chemistry, Atmos. Chem. Phys., 10, 6169-6178, doi:10.5194/acp-10-6169-2010, 2010.

Mari, C., Bechtold, P., and Jacob, D.: Transport and scavenging of soluble gases in a deep convective cloud, J. Geophys. Res., 105, 22 255-22 268, doi:10.1029/2000JD900211, 2000.

Martien, P. T., Harley, R. A., and Cacuci, D. G.: Adjoint Sensitivity Analysis for a Three-Dimensional Photochemical Model: Implementation and Method Comparisons, Environ. Sci. Technol., 40, 
2663-2670, doi:10.1021/es0510257, pMID: 16683606, 2006.

Martin, R. V., Jacob, D. J., Logan, J. A., Ziemke, J. M., and Washington, R.: Detection of a lightning influence on tropical tropospheric ozone, Geophys. Res. Lett., 27, 1639-1642, doi:10.1029/1999GL011181, 2000.

Menut, L., Vautard, R., Beekmann, M., and Honoré, C.: Sensitivity of photochemical pollution using the adjoint of a simplified chemistry-transport model, J. Geophys. Res., 105, 15379-15402, doi:10.1029/1999JD900953, 2000.

Millet, D. B., Jacob, D. J., Custer, T. G., de Gouw, J. A., Goldstein, A. H., Karl, T., Singh, H. B., Sive, B. C., Talbot, R. W., Warneke, C., and Williams, J.: New constraints on terrestrial and oceanic sources of atmospheric methanol, Atmos. Chem. Phys., 8, 68876905, doi:10.5194/acp-8-6887-2008, 2008.

Mollner, A. K., Valluvadasan, S., Feng, L., Sprague, M. K., Okumura, M., Milligan, D. B., Bloss, W. J., Sander, S. P., Martien, P. T., Harley, R. A., McCoy, A. B., and Carter, W. P. L.: Rate of Gas Phase Association of Hydroxyl Radical and Nitrogen Dioxide, Science, 330, 646-649, doi:10.1126/science.1193030, 2010.

Moxim, W. J. and Levy, H.: A model analysis of the tropical South Atlantic Ocean tropospheric ozone maximum: The interaction of transport and chemistry, J. Geophys. Res., 105, 17393-17416, doi:10.1029/2000JD900175, 2000.

Murphy, J. G., Oram, D. E., and Reeves, C. E.: Measurements of volatile organic compounds over West Africa, Atmos. Chem. Phys., 10, 5281-5294, doi:10.5194/acp-10-5281-2010, 2010.

Nassar, R., Logan, J. A., Megretskaia, I. A., Murray, L. T., Zhang, L., and Jones, D. B. A.: Analysis of tropical tropospheric ozone, carbon monoxide, and water vapor during the 2006 El Niño using TES observations and the GEOS-Chem model, J. Geophys. Res. Atmos., 114, D17304, doi:10.1029/2009JD011760, 2009.

Olivier, J. G. J. and Berdowski, J. J. M.: Global emission sources and sinks, Swets \& Zeitlinger, Lisse, The Netherlands, 33-77, 2001.

Palmer, P. I., Jacob, D. J., Fiore, A. M., Martin, R. V., Chance, K., and Kurosu, T. P.: Mapping isoprene emissions over North America using formaldehyde column observations from space, J. Geophys. Res., 108, 4180, doi:10.1029/2002JD002153, 2003.

Paulot, F., Crounse, J. D., Kjaergaard, H. G., Kroll, J. H., Seinfeld, J. H., and Wennberg, P. O.: Isoprene photooxidation: new insights into the production of acids and organic nitrates, Atmos. Chem. Phys., 9, 1479-1501, doi:10.5194/acp-9-1479-2009, 2009a.

Paulot, F., Crounse, J. D., Kjaergaard, H. G., Kurten, A., St. Clair, J. M., Seinfeld, J. H., and Wennberg, P. O.: Unexpected Epoxide Formation in the Gas-Phase Photooxidation of Isoprene, Science, 325, 730-733, doi:10.1126/science.1172910, 2009b.

Paulot, F., Wunch, D., Crounse, J. D., Toon, G. C., Millet, D. B., DeCarlo, P. F., Vigouroux, C., Deutscher, N. M., González Abad, G., Notholt, J., Warneke, T., Hannigan, J. W., Warneke, C., de Gouw, J. A., Dunlea, E. J., De Mazière, M., Griffith, D. W. T., Bernath, P., Jimenez, J. L., and Wennberg, P. O.: Importance of secondary sources in the atmospheric budgets of formic and acetic acids, Atmos. Chem. Phys., 11, 1989-2013, doi:10.5194/acp-11-1989-2011, 2011.

Peeters, J. and Müller, J.-F.: $\mathrm{HO}_{\mathrm{x}}$ radical regeneration in isoprene oxidation via peroxy radical isomerisations. II: experimental evidence and global impact, Phys. Chem. Chem. Phys., 12, 1422714235, doi:10.1039/C0CP00811G, 2010.
Peeters, J., Nguyen, T., and Vereecken, L.: $\mathrm{HO}_{x}$ radical regeneration in the oxidation of isoprene, Phys. Chem. Chem. Phys., 11, 5935-5939, doi:10.1039/b908511d, 2009.

Perring, A. E., Bertram, T. H., Wooldridge, P. J., Fried, A., Heikes, B. G., Dibb, J., Crounse, J. D., Wennberg, P. O., Blake, N. J., Blake, D. R., Brune, W. H., Singh, H. B., and Cohen, R. C.: Airborne observations of total $\mathrm{RONO}_{2}$ : new constraints on the yield and lifetime of isoprene nitrates, Atmos. Chem. Phys., 9, 1451-1463, doi:10.5194/acp-9-1451-2009, 2009a.

Perring, A. E., Wisthaler, A., Graus, M., Wooldridge, P. J., Lockwood, A. L., Mielke, L. H., Shepson, P. B., Hansel, A., and Cohen, R. C.: A product study of the isoprene $+\mathrm{NO}_{3}$ reaction, Atmos. Chem. Phys., 9, 4945-4956, doi:10.5194/acp-9-4945-2009, 2009b.

Pfister, G. G., Emmons, L. K., Hess, P. G., Lamarque, J. F., Orlando, J. J., Walters, S., Guenther, A., Palmer, P. I., and Lawrence, P. J.: Contribution of isoprene to chemical budgets: A model tracer study with the NCAR CTM MOZART-4, J. Geophys. Res., 113, D05308, doi:10.1029/2007JD008948, 2008.

Poisson, N., Kanakidou, M., and Crutzen, P. J.: Impact of Non-Methane Hydrocarbons on Tropospheric Chemistry and the Oxidizing Power of the Global Troposphere: 3Dimensional Modelling Results, J. Atmos. Chem., 36, 157-230, doi:10.1023/A:1006300616544, 2000.

Prather, M. J. and Jacob, D. J.: A persistent imbalance in $\mathrm{HO}_{x}$ and $\mathrm{NO}_{x}$ photochemistry of the upper troposphere driven by deep tropical convection, Geophys. Res. Lett., 24, 3189-3192, doi:10.1029/97GL03027, 1997.

Price, C., Penner, J., and Prather, M.: $\mathrm{NO}_{\mathrm{x}}$ from lightning 1. Global distribution based on lightning physics, J. Geophys. Res., 102, 5929-5942, doi:10.1029/96JD03504, 1997.

Randerson, J. T., van der Werf, G. R., Giglio, L., Collatz, G. J., and Kasibhatla, P. S.: Global Fire Emissions Database, Version 2 (GFEDv2), Tech. rep., Oak Ridge National Laboratory Distributed Active Archive Center, Oak Ridge, TN, USA, doi:10.3334/ORNLDAAC/834, 2006.

Ren, X., Olson, J. R., Crawford, J., Brune, W. H., Mao, J., Long, R. B., Chen, Z., Chen, G., Avery, M. A., Sachse, G. W., et al.: $\mathrm{HO}_{x}$ chemistry during INTEX-A 2004: Observation, model calculation, and comparison with previous studies, J. Geophys. Res., 113, 5310, doi:10.1029/2007JD009166, 2008.

Roberts, J. M. and Fajer, R. W.: UV absorption cross sections of organic nitrates of potential atmospheric importance and estimation of atmospheric lifetimes, Environ. Sci. Technol., 23, 945951, doi:10.1021/es00066a003, 1989.

Roelofs, G. and Lelieveld, J.: Tropospheric ozone simulation with a chemistry-general circulation model: Influence of higher hydrocarbon chemistry, J. Geophys. Res., 105, 22697-22712, doi:10.1029/2000JD900316, 2000.

Sander, R.: Compilation of Henry's Law Constants for Inorganic and Organic Species of Potential Importance in Environmental Chemistry (Version 3), Tech. rep., 1999.

Saunders, S. M., Jenkin, M. E., Derwent, R. G., and Pilling, M. J.: Protocol for the development of the Master Chemical Mechanism, MCM v3 (Part A): tropospheric degradation of nonaromatic volatile organic compounds, Atmos. Chem. Phys., 3, 161-180, doi:10.5194/acp-3-161-2003, 2003.

Sauvage, B., Martin, R. V., van Donkelaar, A., Liu, X., Chance, K., Jaeglé, L., Palmer, P. I., Wu, S., and Fu, T.-M.: Re- 
mote sensed and in situ constraints on processes affecting tropical tropospheric ozone, Atmos. Chem. Phys., 7, 815-838, doi:10.5194/acp-7-815-2007, 2007a.

Sauvage, B., Martin, R. V., Van Donkelaar, A., and Ziemke, J. R.: Quantification of the factors controlling tropical tropospheric ozone and the South Atlantic maximum, J. Geophys. Res., 112, D11309, doi:10.1029/2006JD008008, 2007b.

Schmidt, H. and Martin, D.: Adjoint sensitivity of episodic ozone in the Paris area to emissions on the continental scale, J. Geophys. Res. Atmos., 108, 8561, doi:10.1029/2001JD001583, 2003.

Seinfeld, J. H. and Pandis, S. N.: Atmospheric chemistry and physics: from air pollution to climate change, WileyInterscience, 234-302, 1998.

Sitch, S., Cox, P. M., Collins, W. J., and Huntingford, C.: Indirect radiative forcing of climate change through ozone effects on the land-carbon sink, Nature, 448, 791-794, doi:10.1038/nature06059, 2007.

Sprengnether, M., Demerjian, K. L., Donahue, N. M., and Anderson, J. G.: Product analysis of the $\mathrm{OH}$ oxidation of isoprene and 1, 3-butadiene in the presence of NO, J. Geophys. Res., 107, 4268, doi:10.1029/2001JD000716, 2002.

Stavrakou, T., Peeters, J., and Müller, J.-F.: Improved global modelling of $\mathrm{HO}_{x}$ recycling in isoprene oxidation: evaluation against the GABRIEL and INTEX-A aircraft campaign measurements, Atmos. Chem. Phys., 10, 9863-9878, doi:10.5194/acp-10-98632010, 2010.

Stevenson, D. S., Dentener, F. J., Schultz, M. G., Ellingsen, K., van Noije, T. P. C., Wild, O., Zeng, G., Amann, M., Atherton, C. S., Bell, N., Bergmann, D. J., Bey, I., Butler, T., Cofala, J., Collins, W. J., Derwent, R. G., Doherty, R. M., Drevet, J., Eskes, H. J., Fiore, A. M., Gauss, M., Hauglustaine, D. A., Horowitz, L. W., Isaksen, I. S. A., Krol, M. C., Lamarque, J., Lawrence, M. G., Montanaro, V., Müller, J., Pitari, G., Prather, M. J., Pyle, J. A., Rast, S., Rodriguez, J. M., Sanderson, M. G., Savage, N. H., Shindell, D. T., Strahan, S. E., Sudo, K., and Szopa, S.: Multimodel ensemble simulations of present-day and near-future tropospheric ozone, J. Geophys. Res. Atmos., 111, D08301, doi:10.1029/2005JD006338, 2006.

Stickler, A., Fischer, H., Williams, J., de Reus, M., Sander, R., Lawrence, M. G., Crowley, J. N., and Lelieveld, J.: Influence of summertime deep convection on formaldehyde in the middle and upper troposphere over Europe, J. Geophys. Res. Atmos., 111, D14308, doi:10.1029/2005JD007001, 2006.

Stone, D., Evans, M. J., Commane, R., Ingham, T., Floquet, C. F. A., McQuaid, J. B., Brookes, D. M., Monks, P. S., Purvis, R., Hamilton, J. F., Hopkins, J., Lee, J., Lewis, A. C., Stewart, D., Murphy, J. G., Mills, G., Oram, D., Reeves, C. E., and Heard, D. E.: $\mathrm{HO}_{x}$ observations over West Africa during AMMA: impact of isoprene and $\mathrm{NO}_{x}$, Atmos. Chem. Phys., 10, 9415-9429, doi:10.5194/acp-10-9415-2010, 2010.

Surratt, J. D., Chan, A. W. H., Eddingsaas, N. C., Chan, M., Loza, C. L., Kwan, A. J., Hersey, S. P., Flagan, R. C., Wennberg, P. O., and Seinfeld, J. H.: Reactive intermediates revealed in secondary organic aerosol formation from isoprene, Proc. Natl. Acad. Sci., 107, 6640-6645, doi:10.1073/pnas.0911114107, 2010.

Thompson, A. M., Doddridge, B. G., Witte, J. C., Hudson, R. D., Luke, W. T., Johnson, J. E., Johnson, B. J., Oltmans, S. J., and Weller, R.: A tropical Atlantic paradox: Shipboard and satellite views of a tropospheric ozone maximum and wave-one in
January-February 1999, Geophys. Res. Lett., 27, 3317-3320, doi:10.1029/1999GL011273, 2000.

Thornton, J. A., Wooldridge, P. J., Cohen, R. C., Martinez, M., Harder, H., Brune, W. H., Williams, E. J., Roberts, J. M., Fehsenfeld, F. C., Hall, S. R., Shetter, R. E., Wert, B. P., and Fried, A.: Ozone production rates as a function of $\mathrm{NO}_{x}$ abundances and $\mathrm{HO}_{\mathrm{x}}$ production rates in the Nashville urban plumes, J. Geophys. Res., 107, 4146, doi:10.1029/2001JD000932, 2002.

Val Martin, M., Logan, J. A., Kahn, R. A., Leung, F.-Y., Nelson, D. L., and Diner, D. J.: Smoke injection heights from fires in North America: analysis of 5 years of satellite observations, Atmos. Chem. Phys., 10, 1491-1510, doi:10.5194/acp-10-14912010, 2010.

Valin, L. C., Russell, A. R., Hudman, R. C., and Cohen, R. C.: Effects of model resolution on the interpretation of satellite $\mathrm{NO}_{2}$ observations, Atmos. Chem. Phys., 11, 11647-11655, doi:10.5194/acp-11-11647-2011, 2011.

Van Dingenen, R., Dentener, F. J., Raes, F., Krol, M. C., Emberson, L., and Cofala, J.: The global impact of ozone on agricultural crop yields under current and future air quality legislation, Atmos. Environ., 43, 604-618, doi:10.1016/j.atmosenv.2008.10.033, 2009.

Vautard, R., Beekmann, M., and Menut, L.: Applications of adjoint modelling in atmospheric chemistry: sensitivity and inverse modelling, Environ. Modell. Softw., 15, 703-709, doi:10.1016/S1364-8152(00)00058-X, 2000.

von Kuhlmann, R., Lawrence, M. G., Pöschl, U., and Crutzen, P. J.: Sensitivities in global scale modeling of isoprene, Atmos. Chem. Phys., 4, 1-17, doi:10.5194/acp-4-1-2004, 2004.

Wang, P., Fishman, J., Harvey, V. L., and Hitchman, M. H.: Southern tropical upper tropospheric zonal ozone wave-1 from SAGE II observations (1985-2002), J. Geophys. Res. Atmos., 111, D08305, doi:10.1029/2005JD006221, 2006.

Wang, Y., Jacob, D. J., and Logan, J. A.: Global simulation of tropospheric $\mathrm{O}_{3}-\mathrm{NO}_{x}$-hydrocarbon chemistry 1 . Model formulation, J. Geophys. Res., 103, 10713-10726, doi:10.1029/98JD00158, 1998.

Warneke, C., Holzinger, R., Hansel, A., Jordan, A., Lindinger, W., Pöschl, U., Williams, J., Hoor, P., Fischer, H., Crutzen, P., et al:: Isoprene and Its Oxidation Products Methyl Vinyl Ketone, Methacrolein, and Isoprene Related Peroxides Measured Online over the Tropical Rain Forest of Surinam in March 1998, J. Atmos. Chem., 38, 167-185, 2001.

Wennberg, P. O., Hanisco, T. F., Jaeglé;, L., Jacob, D. J., Hintsa, E. J., Lanzendorf, E. J., Anderson, J. G., Gao, R.-S., Keim, E. R., Donnelly, S. G., Negro, L. A., Fahey, D. W., McKeen, S. A., Salawitch, R. J., Webster, C. R., May, R. D., Herman, R. L., Proffitt, M. H., Margitan, J. J., Atlas, E. L., Schauffler, S. M., Flocke, F., McElroy, C. T., and Bui, T. P.: Hydrogen Radicals, Nitrogen Radicals, and the Production of $\mathrm{O}_{3}$ in the Upper Troposphere, Science, 279, 49-53, doi:10.1126/science.279.5347.49, 1998.

Wesely, M. . L.: Parameterization of surface resistances to gaseous dry deposition in regional-scale numerical models, Atmos. Environ., 23, 1293-1304, doi:10.1016/j.atmosenv.2007.10.058, 1989.

World Health Organization: Air Quality Guidelines Global Update, 2005.

Wu, S., Mickley, L. J., Jacob, D. J., Logan, J. A., Yantosca, R. M., and Rind, D.: Why are there large differences between models in global budgets of tropospheric ozone?, J. Geophys. Res., 112, 
D05302, doi:10.1029/2006JD007801, 2007.

Yienger, J. J. and Levy, H.: Empirical model of global soilbiogenic NOx emissions, J. Geophys. Res., 100, 11447-11464, doi:10.1029/95JD00370, 1995.

Yokelson, R. J., Crounse, J. D., DeCarlo, P. F., Karl, T., Urbanski, S., Atlas, E., Campos, T., Shinozuka, Y., Kapustin, V., Clarke, A. D., Weinheimer, A., Knapp, D. J., Montzka, D. D., Holloway, J., Weibring, P., Flocke, F., Zheng, W., Toohey, D., Wennberg, P. O., Wiedinmyer, C., Mauldin, L., Fried, A., Richter, D., Walega, J., Jimenez, J. L., Adachi, K., Buseck, P. R., Hall, S. R., and Shetter, R.: Emissions from biomass burning in the Yucatan, Atmos. Chem. Phys., 9, 5785-5812, doi:10.5194/acp-9-57852009, 2009.

Zhang, L., Jacob, D. J., Kopacz, M., Henze, D. K., Singh, K., and Jaffe, D. A.: Intercontinental source attribution of ozone pollution at western U.S. sites using an adjoint method, Geophys. Res. Lett., 36, L11810, doi:10.1029/2009GL037950, 2009.

Zhang, L., Jacob, D. J., Liu, X., Logan, J. A., Chance, K., Eldering, A., and Bojkov, B. R.: Intercomparison methods for satellite measurements of atmospheric composition: application to tropospheric ozone from TES and OMI, Atmos. Chem. Phys., 10, 4725-4739, doi:10.5194/acp-10-4725-2010, 2010.
Zhu, T., Barnes, I., and Becker, K. H.: Relative-rate study of the gas-phase reaction of hydroxy radicals with difunctional organic nitrates at $298 \mathrm{~K}$ and atmospheric pressure, J. Atmos. Chem., 13, 301-311, doi:10.1007/BF00058137, 1991.

Ziemke, J. R. and Chandra, S.: Seasonal and interannual variabilities in tropical tropospheric ozone, Journal of Geophysical Research, 1042, 21425-21442, doi:10.1029/1999JD900277, 1999.

Ziemke, J. R., Chandra, S., Duncan, B. N., Froidevaux, L., Bhartia, P. K., Levelt, P. F., and Waters, J. W.: Tropospheric ozone determined from Aura OMI and MLS: Evaluation of measurements and comparison with the Global Modeling Initiative's Chemical Transport Model, J. Geophys. Res. Atmos., 111, D19303, doi:10.1029/2006JD007089, 2006.

Ziemke, J. R., Chandra, S., Duncan, B. N., Schoeberl, M. R., Torres, O., Damon, M. R., and Bhartia, P. K.: Recent biomass burning in the tropics and related changes in tropospheric ozone, Geophys. Res. Lett., 361, L15819, doi:10.1029/2009GL039303, 2009. 